\title{
ПРОБЛЕМНЫЕ ВОПРОСЫ И ПУТИ ПОВЫШЕНИЯ ЭФФЕКТИВНОСТИ СЕЙСМОРАЗВЕДКИ
}

\section{Часть II}

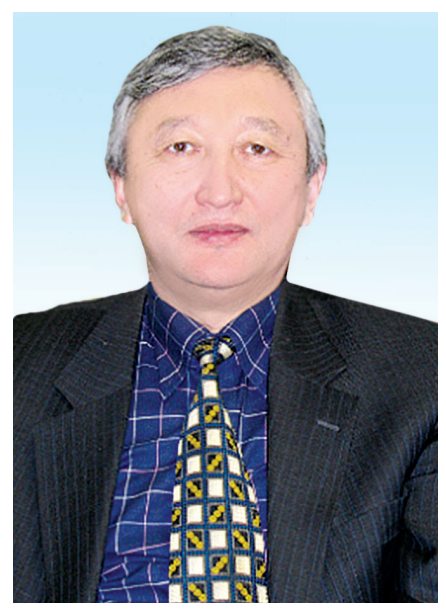

С.М. ИСЕНОВ*,

кандидат геол.-мин. наук, Почетный разведчик недр РК, главный геофизик, https://orcid.org/0000-0003737-2336

ТОО «ГЕОМЕДЖ КZ»

Республика Казахстан, 050000, г. Алматы, ул. Богенбай батыра, 132

Рассмотрены пути и практические примеры повышения эфффективности сейсморазведки, на основе улучшения количественных оценок Сигнал/Помеха и вертикальной разрешающей способностью сейсмической записи при проведении полевых сейсмических наблюдений, обработки и интерпретации сейсмоданных. Существенное улучшение качества и детальности сейсмического изображения среды будет обеспечено при применении высокоплотных систем полевой сейсмосъемки и увеличении кратности наблюдений и технологии обработки, в которых базовые математические модели основаны на волновой природе формирования сейсмических сигналов в пределах первой зоны Френеля. Эффрективность технологий сейсмогеологической интерпретации зависит от степени соответствия базовых математических моделей реальному строению геологического разреза, что будет определять достоверность прогнозирования вещественного состава отложений и физических параметров резервуаров углеводородов.

КЛЮЧЕВЫЕ СЛОВА: геологические задачи сейсморазведки МОГТ, фризические возможности и ограничения сейсморазведки, технологии Мультифоокусинг, количественные оценки Сигнал/Помеха и вертикальная разрешающей способность, прогнозирование вещественного состава отложений и фризических параметров резервуаров, неопределенности при геологическом и гидродинамическом моделировании.

\footnotetext{
*Адрес для переписки. E-mail: serik.issenov@gmail.com
} 


\title{
СЕЙСМИКАЛЫҚ БАРЛАУ ТИІМДІЛІГІН АРТТЫРУ ЖОЛДАРЫ ЖӘНЕ КҮРДЕЛІ МӘСЕЛЕЛЕР. II БОЛІМ
}

\author{
С.М. ИСЕНОВ ${ }^{*}$, геол.-мин. ғыл. канд., бас геофизик, https://orcid.org/0000-0003-737-2336 \\ «ГЕОМЕДЖ KZ» ЖШС \\ Қазақстан Республикасы, 050000, Алматы қ-сы, Бөгенбай батыр к-сі,132
}

Далалық сейсмикалық түсірілім мен өңдеу және түсіндіру кезіндегі сандық Сигнал/Шу бағалары мен сейсмикалық жазбаның вертикаль тұнықтық қабілетін жақсартуға негізделген сейсмобарлау тиімділігін арттыру жолдары мен практикалық үлгілері қарастырылған. Ортаның сейсмикалық кескінінің сапасы мен дәлдігін бақылаулар жиілігінің едәуір артуымен тығыздығы жоғары далалық сейсмикалық жүйелерді қолдану және негізгі математикалық модельдер бірінші Френель зонасында сейсмикалық сигналдардың пайда болуының толқындық сипатына негізделген өңдеу технологияларын қолдану айтарлықтай арттырады. Сейсмогеологиялық түсіндіру технологиясының тиімділігі базалық математикалық үлгісінің геологиялық қиманың нақты құрылымына сәйкестік дәрежесіне байланысты, бұл шөгінділердің материалдық құрамы мен көмірсутегі қоймаларының физикалық параметрлерін болжау сенімділігін анықтайды.

ТҮЙІн сөзДЕР: ЖТНТ (МОГТ) сейсмикалық барлаудағы геологиялық мәселелер, сейсмикалық барлаудың фризикалық мүмкіндіктері мен шектеулері, Мультифоокусинг технологиясы, сандық Сигнал/Шу бағалары мен вертикаль тұнықтық қабілет, шөгінділердің заттық құрамы мен қоймалардың фризикалық параметрлерін болжау, геологиялық және гидродинамикалық модельдеудегі белгісіздіктер.

\section{PROBLEM ISSUES AND WAYS OF INCREASE THE EFFICIENCY OF SEISMIC SURVEY. PART II}

S.M. ISSENOV*, Candidate of Geological and Mineralogical Sciences, Chief Geophysicist, https://orcid.org/0000-0003-737-2336

«GEOMAGE-KZ»LLP

132, Bogenbay batyr, str., Almaty, Republic of Kazakhstan, 050000

Ways and practical examples of increasing the efficiency of seismic exploration are considered, based on improving the quantitative estimates of Signal/Noise ratio and the vertical resolution of seismic records when conducting field seismic survey, processing and interpreting seismic data. A significant improvement in the quality and detail of the seismic image of the environment will be ensured by using high-density field seismic systems with a significant increase in the frequency of observations and processing technologies, in which the basic mathematical models are based on the wave nature of the formation of seismic signals within the first Fresnel zone. The effectiveness of seismic-geological interpretation technologies depends on the degree of correspondence of the basic mathematical models to the real structure of the geological section, which will determine the reliability of predicting the material composition of deposits and the physical parameters of hydrocarbon reservoirs.

KEY WORDS: geological problems of CDP seismic exploration, physical capabilities and limitations of seismic exploration, Multifocusing technologies, quantitative estimates of Signal / Noise and vertical resolution, prediction of the material composition of sediments and physical parameters of reservoirs, uncertainties in geological and hydrodynamic modeling.

\section{ВВЕДЕНИЕ} первой части данной статьи были рассмотрены основные факторы, ограничивающие эффективность и результативность сейсморазведочных исследований [1]. Было отмечено, что искажающее влияние некоторых факторов может 
быть учтено с высокой точностью, части факторов - приближенно, а таких факторов как обменные и частично-кратные волны, тонкослоистость и многофазность реальной среды вообще не поддаются коррекции или корректируются с невысокой точностью $[2,3]$. Эти факторы связаны как со сложностью и особенностями строения геологической среды и состава регистрируемого сейсмического волнового поля, так и степенью адекватности базовых математических моделей особенностям строения изучаемой реальной среды. Общепринятые методики и технологии сейсморазведки обеспечивают в большинстве случаев решение структурно-тектонических задач, но продолжает оставаться проблематичной достоверность решения задач изучения детального геологического строения продуктивных слоев и резервуаров, включая «динамический» анализ сейсмических записей при прогнозировании вещественного состава отложений и парамеров коллекторов.

Известно, что снижение эффективности сейсморазведки методом ОГТ наблюдается по мере усложнения строения геологической среды, увеличения глубинности исследований, при изучении неглубоко залегающих объектов, при детальном изучении внутреннего строения продуктивных толщ и резервуаров УВ и пр. Применение более эффективных инновационных методик и технологий сейсморазведки, включая полевые системы наблюдения, обработку и интерпретацию сейсмоданных, приведет к повышению количественных оценок Сигнал/Помеха и разрешенности сейсмической записи. Применение инноваций зависит от информированности руководства компаний недропользователей о новых возможностях повышения эффективности проектов разведки и доразведки месторождений УВ, от которых зависит открытие новых местороождений, снижение рисков глубокого бурения и повышение эффективности разработки.

Во второй части статьи приведены некоторые практические результаты повышения эффективности сейсморазведки, полученных в последние годы в разных сейсморазведочных проектах РК, а также из опубликованных источников. Рассмотренные примеры демонстрируют пути повышения качества и полноты сейсмических изображений среды на этапах полевой сейсмосъемки и обработки сейсмоданных. Дальнейшая интерпретация улучшенного качества сейсмических записей и изображений среды повысит достоверность и расширит круг решаемых геологических задач в разных сейсмогеологических условиях.

\section{О ВЛИЯНИИ ПЛОТНОСТИ И КРАТНОСТИ ПОЛЕВЫХ СЕЙСМИЧЕСКИХ НАБЛЮДЕНИЙ НА РЕЗУЛЬТАТЫ СЕЙСМОРАЗВЕДКИ}

Очевидно, что качество исходных полевых сейсмических записей существенным образом определяет результативность сейсморазведки. При постановке целевых геологических задач и проектировании нового проекта сейсморазведки обычно выполняют анализ ранее выполненных сейсморазведочных исследований, влияния искажающих факторов в приповерхностных и глубинных сейсмогеологических условиях. Не всегда должное внимаие уделяется опытно-методическим работам (ОМР), предназначенных для выбора оптимальной методики и технологии сейсмических наблюдений на основе более совершенных технических средств. Также необходимо определить состав вспомогательных видов исследований неоднородно- 


\section{РАЗВЕДКА}

стей в верхней части разреза (ВЧР), от учета искажающего влияния которых будет зависеть решение целевых геологических задач.

Ожидаемую эффективность сейсморазведки методом ОГТ обычно оценивают по кратности $(N)$ перекрытия полевых сейсмических наблюдений в пределах бина или «точки» ОГТ, которая определяет статистический эффект суммирования сигналов $\sqrt{\boldsymbol{N}}[4]$. Другими важными параметрами полевой 3Д сейсмосъемки являются плотность наблюдений на 1 кв. км, широкоазимутальность расстановки, максимальные удаления взрыв-прием и др. Значительное увеличение плотности и кратности систем наблюдений приведет как к повышению качества результатов сейсморазведки, так и к избыточности информации, если учитывать волновую природу сейсмических волн. Поэтому к статистическому эффекту суммирования сигналов начали добавлять поправочный коэффициент $-\boldsymbol{k} \sqrt{\boldsymbol{N}}$, чтобы лучше соответствовать количественным и визуальным оценкам соотношения Сигнал/Помеха $(\mathrm{C} / П)$ на сейсмических разрезах и кубах.

На рисунке 1 приведены сечения кубов временной миграции до суммирования (PSTM), на которых сравниваются сейсмические изображения и прослеживание подсолевых опорных отражающих горизонтов, при изменении кратности суммирования 3 Д ОГТ при $N=60,100,200$ и 400. По мере увеличения кратности ОГТ статистический эффект суммирования сигналов растет в 1,3, 1,8 и 2,6 раза, относительно исходной кратности $N=60$ (рисунок 1,2 ), что хорошо согласуются с визуальными оценками качества сейсмической записи. На кубе PSTM с кратностью ОГТ $N=400$ (рисунок $1, a$ ) подсолевой карбонатный резервуар (выделен синим контуром) освещается энергетически слабыми второстепенными отражениями, которые прослеживаются с перерывами и имеют низкую вертикальную разрешающую спо-

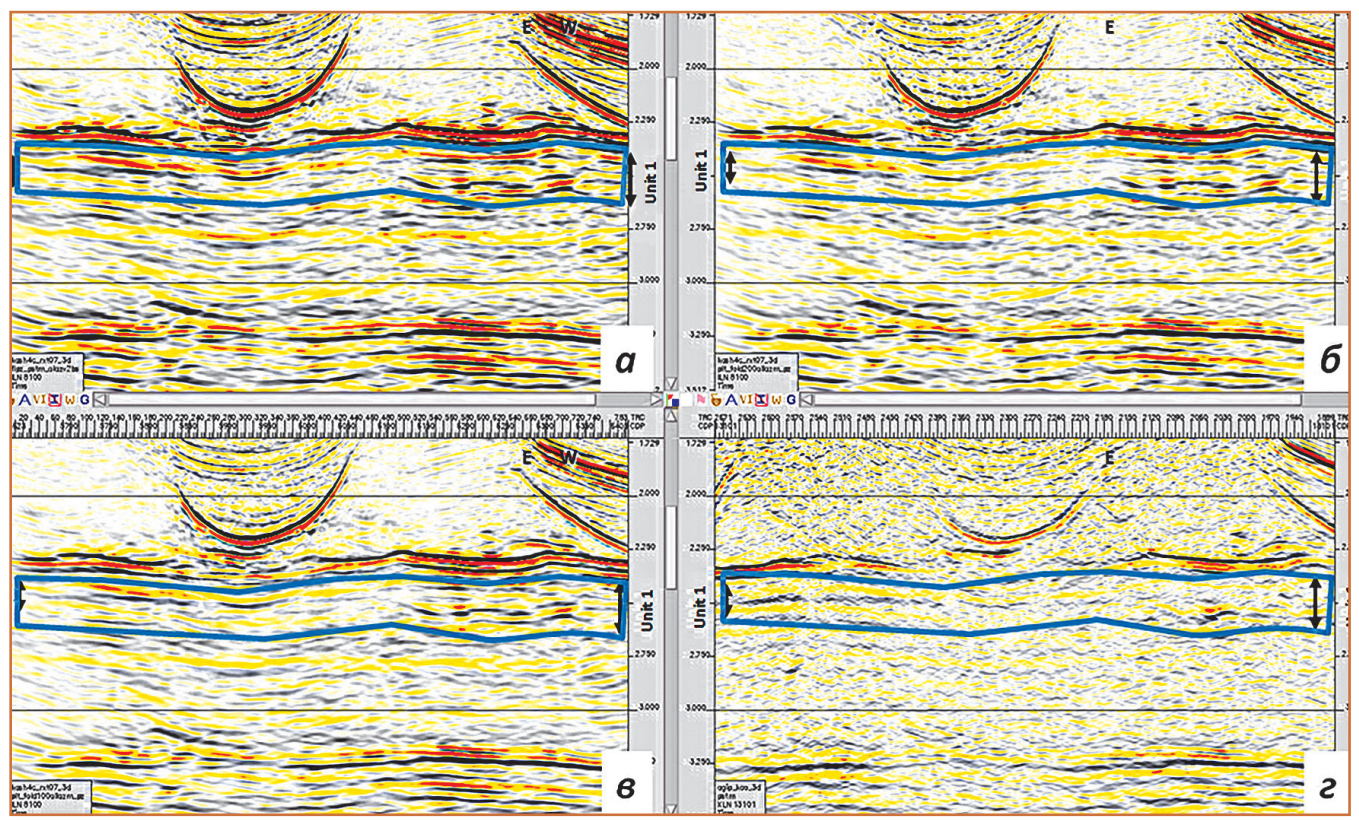

Рисунок 1 - Сравнение сечений кубов PSTM (из материалов Agip KCO) при кратности ОГТ: $a-400,6-200$, в -100, г - 60 
собность. Качеству визуального прослеживания этих второстепенных отражений соответствует оценка $\mathrm{C} /$ П $<1-1,5$. При таком качестве сейсмической записи, вряд ли можно корректно решить задачу детального изучения геологического строения подсолевого карбонатного резервуара $[3,5,6,7]$.

Новое поколение полевой технологии сверхплотной и широкоазимутальной 3Д сейсморазведки получило все большее применение в последние 10-15 лет, с целью повышения эффективности сейсморазведки и достоверности решения геологических задач исследований. В сверхплотных системах наблюдения применяют одиночные источники и приемники или малые размеры их группирования, «сверхмногоканальные» регистрирующие системы с активными каналами от сотен тысяч до первых сотен миллионов, с уменьшением шага пунктов приема до нескольких меторов. Это повысило качество сейсмических изображений среды и некоторое увеличение разрешающей способности сейсмической записи, за счет расширения частотного диапазона в сторону высоких частот [8].

На рисунке 2 приведено сравнение результатов 3Д сейсморазведок (Китай), выполненных с группированием геофонов и с применением одиночных акселерометров (из материалов А.В. Череповского). В первом проекте плотность наблюдений составила 48000 трасс/1кв.км при кратности ОГТ $N=60$ и размере бина $25 \times 50$ м, во втором проекте плотность наблюдений была увеличена до 480000 трасс/1кв. км при кратности ОГТ $N=96$ и размере бина 10х20 м. Десятикратное увеличение плотности размещения одиночных акселерометров обеспечило заметное повышение разрешенности сейсмического изображения и, что важно, выделение отражения от ВНК в нефтяной залежи (рисунок 2, б).

В современных проектах сверхплотной и широкоазимутальной 3 Д сейсморазведки, выполненных в северной части Африки и на Аравийском полуострове, плотность наблюдений достигла 100 млн.трасс/1 кв.км при кратности перекрытия ОГТ до 8000 (была уменьшена до 6400 при ограничении удаления взрыв-прием до 4000 м),

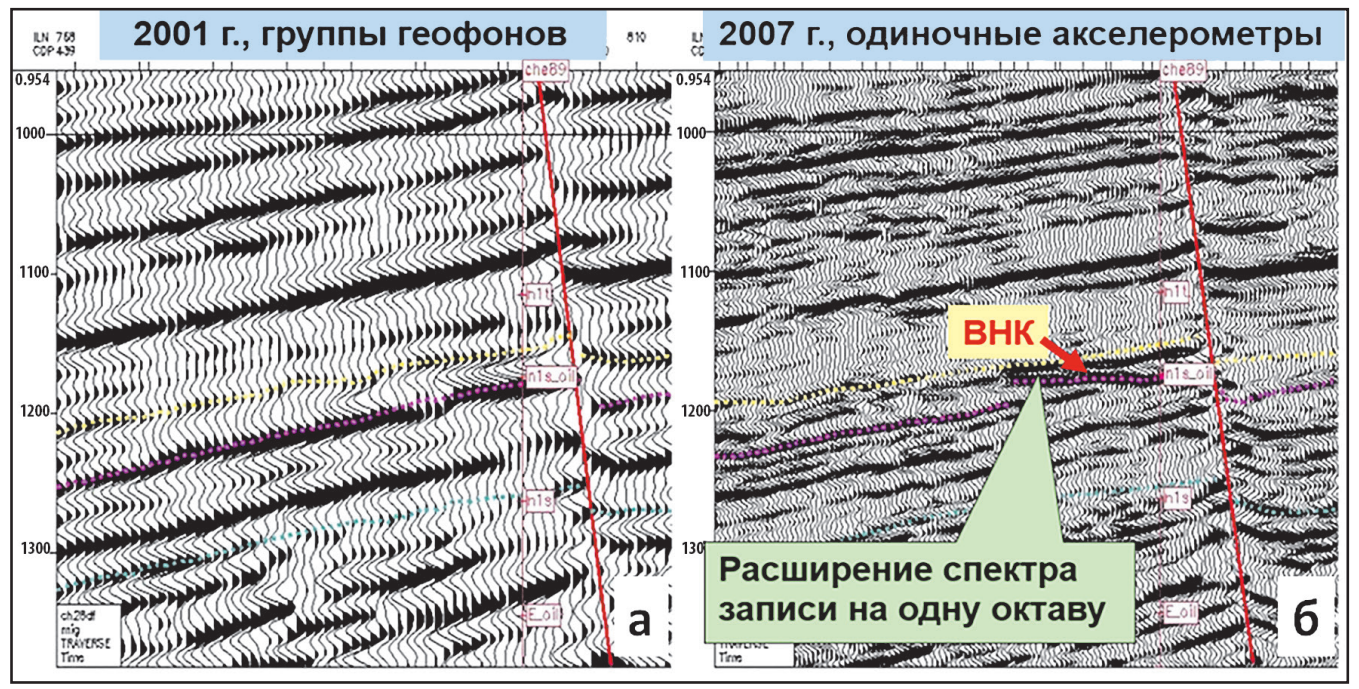

Рисунок 2 - Сравнение фрагментов ЗД сейсмосъемок:

a - с группированием геофонов; 6 - с одиночными акселерометрами

HЕФТЬ И ГАЗ 20212 (122) 
рекордное значение плотности наблюдений 184 млн.трасс/1 кв.км [8]. В Казахстане в нескольких проектах также была применена методика сверхплотной широкоазимутальной 3Д сейсморазведки. На месторождении Карачаганак плотность наблюдений составила 3300 000/1 кв.км, при кратности $N=330$ и размере бина 10x10 м, а на месторождении Аксай плотность наблюдений достигла 6380 000/1 кв.км, при кратности $N=924$ и размере бина $10 \times 10$ м [9].

При подготовке проекта сверхплотной широкоазимутальной 3Д сейсморазведки (2009 г.) на месторождении Карачаганак большое внимание было уделено вопросам компенсации влияний мешающих факторов, которые существенно ухудшили качество результатов ЗД сейсморазведки 1999 г. К этим факторам относятся: малая кратность перекрытия ОГТ $N=40$; специфические волны-помехи, которые удалось подавить только после применения нестандартной программной процедуры; сложная форма соляного купола (площадью до 300 кв. км), кровля соляного купола является сильной преломляющей границей для сейсмических волн, которая залегает на глубине 200-400 м и имеет холмистую поверхность.

В процессе итеративной обработки по технологии глубиной миграции до суммирования (PSDM, RTM) была выполнена оптимизация параметров глубинно-скоростной модели и был укрупнен размер бина до 30х30 м, что повысило статистический эффект суммирования сигналов в 8,6 раз относительно 3Д сейсмоданных 1999 г. Т.о. качество сейсмического изображения было значительно улучшено по всей глубине результативного куба PSDM. В то же время, целевой интервал карбонатного резервуара (высотой в каменоугольных отложениях до 800 м и совместно с нижнепермской постройкой высотой до 1600 м) освещен слабыми нерегулярными отражениями с низкой ветикальной разрешенностью. После дополнительной полосовой фильтрации глубинного куба PSDM в интервале резервуара появились наклонные элементы (рисунок 3), которые объясняют проградационными условиями осадконакопления большой толщины карбонатных отложений с косой слоистостью, которая должна бы наблюдаться также на керне и данных FMI. Пока нет ответа на следующие вопросы: «Не являются ли эти наклонные элементы помехами процедуры полосовой фильтрации в интервале слабой и нерегулярной записи? Откуда мог происходить снос осадков, чтобы в условиях морской изолированной карбонатной постройки сформировать большой толщины отложения с косой слоистостью?».

На месторождении Тенгиз в 2009-2010 гг. была выполнена 3Д сейсморазведка с применением взрывных источников возбуждения, кратностью ОГТ $N=220$ и размером бина 20х20 м. Статистический эффект суммирования сигналов был увеличен всего в 2,4 раза, в сравнении с предыдущей 3Д сейсморазведкой (1999-2000 гг.) с

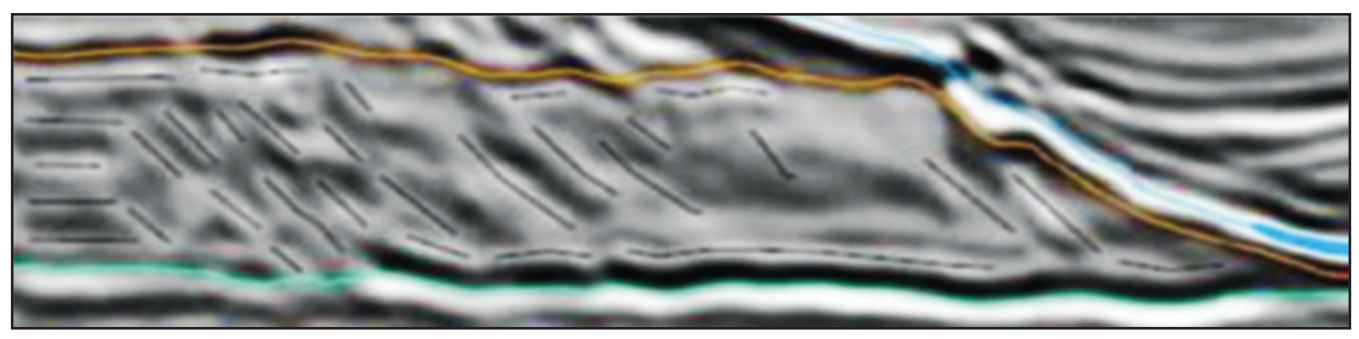

Рисунок 3 - Фрагмент глубинного куба в интервале подсолевого карбонатного резервуара 
кратностью ОГТ $N=60$ и размере бина $25 \times 25$ м. Ожидалось, что данная методика обеспечит существенное улучшение качества и разрешенности сейсмического изображения разреза и детальное изучение геологического строения подсолевого карбонатного резервуара высотой более 1500 м. Однако, не был учтен опыт ранее выполненных проектов сейсморазведки в Прикаспийской впадине, что взрывные скважины необходимо бурить глубже слоя синих глин. Сравнение полевых сейсмограмм 1999 г. и 2010 г. показало незначительные различия в сейсмических записях и амплитудно-частотных спектрах. Возможно поэтому результаты новой 3 Д сейсморазведки оказались недостаточно информативными и необеспечившими решение целевых задач исследований (из неофициальных источников).

При изучении трехмерных сложнопостроенных сред необходимо правильно определить параметр азимутальности 3 Д сейсморазведочных наблюдений. На глубинном кубе PSDM, полученном по данным высокоплотной полноазимутальной 3Д сейсморазведки (рисунок 4, $a$ ), сейсмическое изображение среды значительно лучше по всей глубине разреза, включая выделение целевых карбонатных объектов, в сравнении с результатом узкоазимутальной 3Д сейсмосъемки (рисунок 4, б) [10].

Методика высокоразрешающей сейсморазведки (BPC) предназначена для существенного повышения разрешающей способности сейсмической записи, при этом будут увеличены доминирующие частоты полезных отраженных сигналов и расширен частотный спектр сейсмической записи в сторону высоких частот. В методике ВРС уменьшают вес заряда и шаг между одиночными пунктами взрывов и приема до нескольких метров. К факторам, ограничивающим эффективность наземной методики ВРС, относят небольшую глубину проникания в геологическую среду высокочастотных компонент спектра сигналов и разного рода неоднородности в приповерхностной и верхней частях разреза, компенсировать искажающее влияние которых проблематично в процессе обработки данных ВРС [11].



Рисунок 4 - Сравнение ЗД сейсмосъемок: а - полноазимутальной ультра-высокоплотной, б - узкоазимутальной высокоплотной

НЕФТЬ И ГАЗ 20212 (122) 


\section{РАЗВЕДКА}

Более благоприятными для ВРС являются морские условия проведения сейсмосъемки, где практически идентичные условия возбуждения и регистрации сейсмических колебаний, и при относительно ровной поверхности дна. Сравнение временных разрезов ОГТ 2Д морской среднечастотной сейсморазведки (1995 г., «Western Geophysical») и дублирующего профиля 2Д ВРС (2007 г., OOO «PGS-Xaзар», экспресс-обработка «Paradigm Geophysical») показывает, что на результатах морской 2Д ВРС существенно повышена разрешенность сейсмической записи и значительно улучшено прослеживание отражений, характеризующих внутреннее строение потенциально продуктивных юрского и мелового комплексов отложений (рисунок 5). Основные параметры морской ВРС: общий объем группы пневмопушек 376 куб. дюймов, шаг ПВ - 12,5 м, регистрация на стримере пъезоприемниками с шагом 6,25 м (в ближней зоне до 900 м) и 12,5 м (в дальней зоне до 1500 м), кратность ОГТ $N=36 / 60$. На разрезе ВРС (рисунок 5,6 ) амплитудно-частотный спектр расширился в сторону высоких частот в $\sim 2$ раза и доминирующие частоты отраженых волн увеличились от 50-60 Гц на разрезе ОГТ до 60-75 Гц, по сравнению с разрезом ОГТ среднечастотной сейсморазведки (рисунок $5, a)$. Тем не менее, в проектах морской сейсморазведки при разведке юрско-меловых структур продолжают применять методику среднечастотной сейсморазведки, для которой параметры системы наблюдений были определены по данным ОМР (1995 г.), направленых на изучение подсолевого палеозойского комплекса отложений.

На основе рассмотреных примеров зависимости качества результатов 3 Д сейсморазведки от плотности и кратности полевых сейсмических наблюдений сделаем следующие выводы:

1. Эффективность и результативность ЗД сейсморазведки возрастают при повышении плотности, кратности и широкоазимутальности сейсмосъемки, а также применении современных сейсмоприемников и многокональных систем регистра-

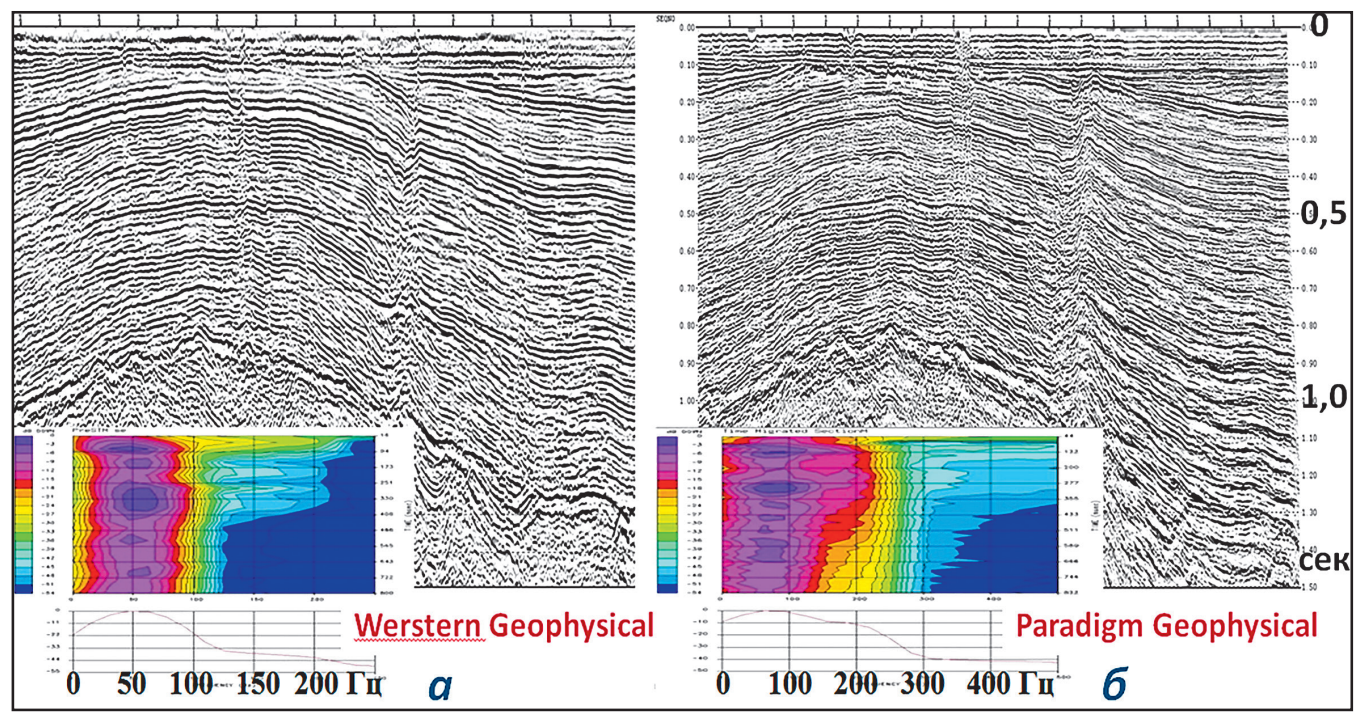

Рисунок 5 - Сравнение морской сейсморазведки: а - среднечастотная ОГТ, б - ВРС (из материалов ТОО «Курмангазы Петролеум») 
ции, что обеспечит решение целевых задач исследований в условиях трехмерных сред. На основе повышенного качества сейсмического изображения среды будут уменьшены риски бурения разведочных и эксплуатационных скважин. Применение узкоазимутальной высокоплотной 3Д сейсморазведки может оправдано при относительно простом строении геологического разреза;

2. Среднечастотный состав и разрешающая способность сейсмической записи на данных высокоплотной широкоазимутальной 3Д сейсморазведки в основном определяются характеристиками источников возбуждения и в меньшей степени зависят от характеристик современных сейсмоприемников (вибраторы обычно возбуждают сейсмические колебания в полосе частот от 8-10 Гц до 90-120 Гц);

3. Применение методики морской высокоразрешающей сейсморазведки (ВРС) существенно повысит разрешающую способность сейсмической записи.

\section{О ЗАВИСИМОСТИ ЭФФЕКТИВНОСТИ ТЕХНОЛОГИЙ ОБРАБОТКИ СЕЙСМОДАННЫХ ОТ БАЗОВЫХ МАТЕМАТИЧЕСКИХ МОДЕЛЕЙ СРЕДЫ}

Основной целью цифровой обработки полевых сейсмоданных является получение сейсмического изображения среды, с теми соотношениями Сигнал/Помеха и разрешающей способностью сейсмической записи, которые обеспечивают решение задач изучения строения геологического разреза и прогнозирование вещественного состава и физических параметров отложений. Программные технологии обработки по методике ОГТ данных сейсморазведки постоянно совершенствуются, при этом отмечают отставание в развитии этих технологий для обработки и интерпретации данных высокоплотной широкоазимутальной 3Д сейсморазведки [10]. Информативность сейсморазведки методом ОГТ, включая этап обработки сейсмоданных, достигла или близка к пределу своих возможностей, о чем косвенно свидетельствовуют факты уменьшения количества открытий новых месторождений УВ и снижении объемов добычи нефти, несмотря на известный прогресс в современных методах и технологиях ГРР, это было отмечено в 1-й части статьи.

Эффективность обработки сейсмоданных зависит от базовых математических моделей среды. В основе сейсморазведочного метода ОГТ лежит математическая модель среды с плоскими субгоризонтальными границами раздела, положительным вертикальным градиентом средней скорости распространения сейсмических волн и упрощенной гиперболической формой годографа отраженной волны (Модель МОГТ). Технология PSDM увеличивает эффективность обработки сейсмоданных в условиях сложнопостроенных сред, которые могут быть описаны задаваемой глубинно-скоростной моделью (Модель PSDM). При этом качество результатов PSDM зависит от степени адекватности параметров Модели PSDM строению изучаемой среды, что также является основной задачей кинематической интерпретации данных сейсморазведки $[12,13]$. Ниже кратко рассмотрим математическую основу технологии Мультифокусинг (МФ) и практические результаты обработки сейсмоданных в разных сейсмогеологических условиях, в сравнении с результатами обработки по стандартной методике ОГТ.

Технология Мультифокусинг предназначена для существенного улучшения качества сейсмических изображений среды, в т.ч. результатов обработки сейсмо- 
данных по технологии PSDM. В основе метода МФ лежит оригинальное математическое решение, описывающее форму фронта отраженной волны для широкого класса моделей среды, с учетом волновой природы формирования отраженного сигнала в пределах 1-й зоны Френеля (Б. Гельчинский, 1992 г. А. Беркович и др., 1994 г.). В методе МФ формула, описывающая фронт отраженной волны, включает три параметра по осям $\boldsymbol{X}$ и $\boldsymbol{Y}$ : угол $\boldsymbol{\beta}$ подхода волны к центральной точке и радиусов кривизны двух фундаментальных волновых фронтов $-\boldsymbol{R}_{\boldsymbol{C R E}}$ и $\boldsymbol{R}_{\boldsymbol{C E} \boldsymbol{E}}$. При обработке 2 Д сейсмоданных рассчитываются 3 указанных параметра МФ, а для 3 Д сейсмоданных - 8 параметров МФ. Формирование сейсмограмм МФ выполняется из трасс обработанных сейсмограмм ОГТ в пределах «супербазы» в центральной части 1-й зоны Френеля, размер которой увеличивается с глубиной и временем регистрации отраженных сигналов. В результате кратность сейсмограмм МФ на 1-2 порядка больше кратности исходных сейсмограмм ОГТ, что увеличивает статистический эффект суммирования сигналов от 5-7 раз в верхней и до 12-15 раз в нижней частях разреза. Формула ввода кинематических поправок МФ приводит к практически идеальному спрямлению отраженных волн на сейсмограмме МФ, сформированной из сейсмограмм ОГТ (рисунок 6, a), при этом на удаленных трассах отсутствуют кинематические «растяжки» записи (рисунок 6, б). Собственно обработка сейсмоданных методом МФ заключается в переборе всех сочетаний параметров МФ и расчете коэффициентов когерентности выделяемых волн, что требует применения супермощных компьютерных систем. По главному максимуму многопараметрической функции когерентности определют параметры МФ для каждого элемента отраженных волн вдоль всего профиля $[14,15]$.

На суммарных разрезах и кубах МФ, полученных в разных сейсмогеологических условиях, наблюдается значительное повышение качества сейсмического изображения прослеживание основных и энергетически слабых второстепенных отражающих горизонтов, характеризующих внутреннее строение продуктивных комплексов отложений, а также отражений в верхнем интервале накопления кратности ОГТ. Также улучшается выделение тектонических нарушений и обеспечивается сохранение относительных амплитуд на результатах МФ, количественные оценки соотношения Сигнал/Помеха (C/П) увеличиваются в среднем до 2-3 раз и более, а разрешенность записи - до 10-15\%.

В процессе получении суммарных временных разрезов и кубов МФ формируется набор параметров МФ, рассчитанных для всех элементов поля отраженных волн. Одной из функций технологии МФ является формирование набора улучшенных (MF-Enhanced) сейсмограмм МФ с повышенным отношением Сигнал/Помеха, на основе рассчитанных параметров МФ и при частичном когерентном суммировании записей на сейсмограммах ОГТ (рисунок 6, б и г). При формировании улучшенных сейсмограммах МФ параметры системы наблюдения могут задаваться совпадающими или отличающимися от местоположения трасс на исходных сейсмограмм ОГТ [16]. На сейсмической записи улучшенных сейсмограмм МФ выделяются все отраженные и дифрагированные волны, в т.ч. с негиперболической формой годографов, при этом отсутствуют низко- и среднескоростные линейные волны-помехи, которые были пропущены при стандартной обработке по методике ОГТ, а также обеспечено сохранение относительных амплитуд и более точное определение времен прихода отраженных волн (рисунок 6, в, г). 


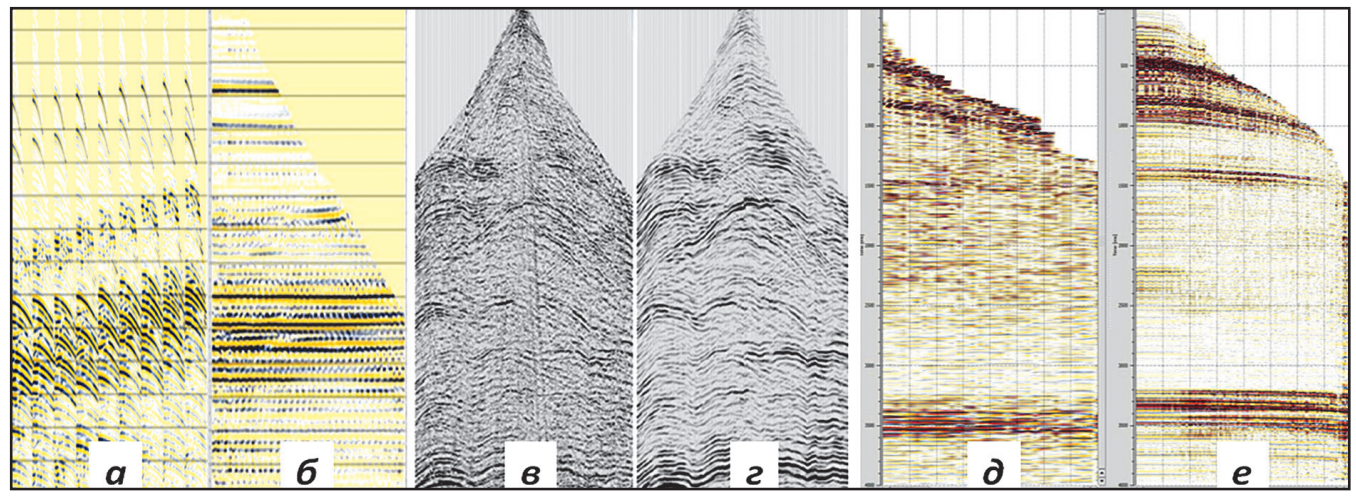

Рисунок 6 - Сравнение сейсмограмм ОГТ и МФ: $a, 6, \partial$ - сейсмограммы ОГТ, 6 - сейсмограмма МФ после ввода кинематических поправок, $2, e-$ улучшенные сейсмограммы МФ

В начальный период обработки с применением технологии МФ были отмечены как преимущества, так и недостатки: большая чувствительность метода МФ и возможность выделения помех, снижение латеральной разрешенности на разрезах МФ за счет улучшения соотношения С/П, высокие стоимость и ресурсоемкость [17]. В процессе совершенствования методики обработки МФ указанные недостатки, за исключением ресурсоемкости, были сняты, включая значительное снижение стоимости.

Приведем отличительные свойства (преимущества) технологии Мультифокусинга:

1. Значительное увеличение статистического эффекта накапливания сигналов и направленности системы при суммирования сейсмических записей и в сейсмограммах МФ, сформированных по принципу общности 1-й зоны Френеля;

2. Сохранение исходной разрешенности сейсмической записи, из-за отсутствия эффекта растяжения записи на удаленных трассах после ввода кинематических поправок и последующего суммирования вдоль фронтов отраженных волн, соответствующих оптимальному сочетанию параметров МФ. Это повышает точность анализа сейсмических скоростей и «динамического» анализа сейсмической записи;

3. Учёт локальной негиперболичности годографов отраженных волн и более точная оценка времен вступления отраженной волны, что важно для повышения качества сейсмического изображения в условиях сложнопостроенных сред;

4. Обработка сейсмограмм МФ и ОГТ может выполняться в условиях сложного рельефа местности, где выполняются сейсмические наблюдения;

5. Повышение качества результатов PSDM за счет использования улучшенных сейсмограмм МФ до суммирования и формирования более достоверной Модели PSDM по улучшенному суммарному разрезу или кубе МФ;

6. Дополнительная обработка по методике ОГТ улучшенных сейсмограмм МФ для улучшения сейсмических изображений на результативных разрезах и кубах МФ.

Эффективность технологии Мультифокусинг в зависимости от кратности ОГТ. Сравним суммарный разрез ОГТ с кратностью $N=120$ (предгорья Канады) с вариантами суммарных (без миграции) сейсмических разрезов МФ, полученных с прореживанием исходных сейсмограмм ОГТ с кратностью $N=120,60,30$. На всех вариантах разрезов МФ качество изображений существенно выше, чем на разрезе 


\section{РАЗВЕДКА}

ОГТ, что подтверждает эффективность свойства «увеличение статистического эффекта накапливания сигналов и эффекта направленности системы» в технологии МФ (рисунок 7). Незначительное ухудшения изображения наблюдаются в верхнем интервале накопления кратности МФ, при кратности исходных сейсмограмм ОГТ $N=30$, остальные геологические особенности на сейсмической записи сохранены в полной мере (рисунок 7). Данный пример свидетельствует об избыточности информации на исходных сейсмограммах ОГТ и позволил сделать вывод о возможности, в рассматриваемом случае, уменьшения кратности перекрытия ОГТ с $N=120$ до $N=60$ за счет разряжения пунктов возбуждения, при этом на результативном разрезе МФ было получено высококачественное изображение разреза. Экономия такого проекта сейсморазведки может составить до $30 \%$, при росте производительности полевой сейсмосъемки [15].

Для учета фактической топографии рельефа сейсмосъемки и статических поправок, при обработке по методикам ОГТ и МФ (рисунок 7, 9,2 и 12,1) была применена программная разработка «Geomage Statics and MultiFocusing® Imaging» («Geomage, LTD»).

Применение технологии МФ по ЗД сейсмоданным (1991 г.) с очень низкой кратностью перекрытия ОГТ $N=12$, обеспечило существенное повышение качества сейсмического изображения среды, в условиях развитой солянокупольной тектоники Прикаспийской впадины (из материалов «Geomage, LTD»).

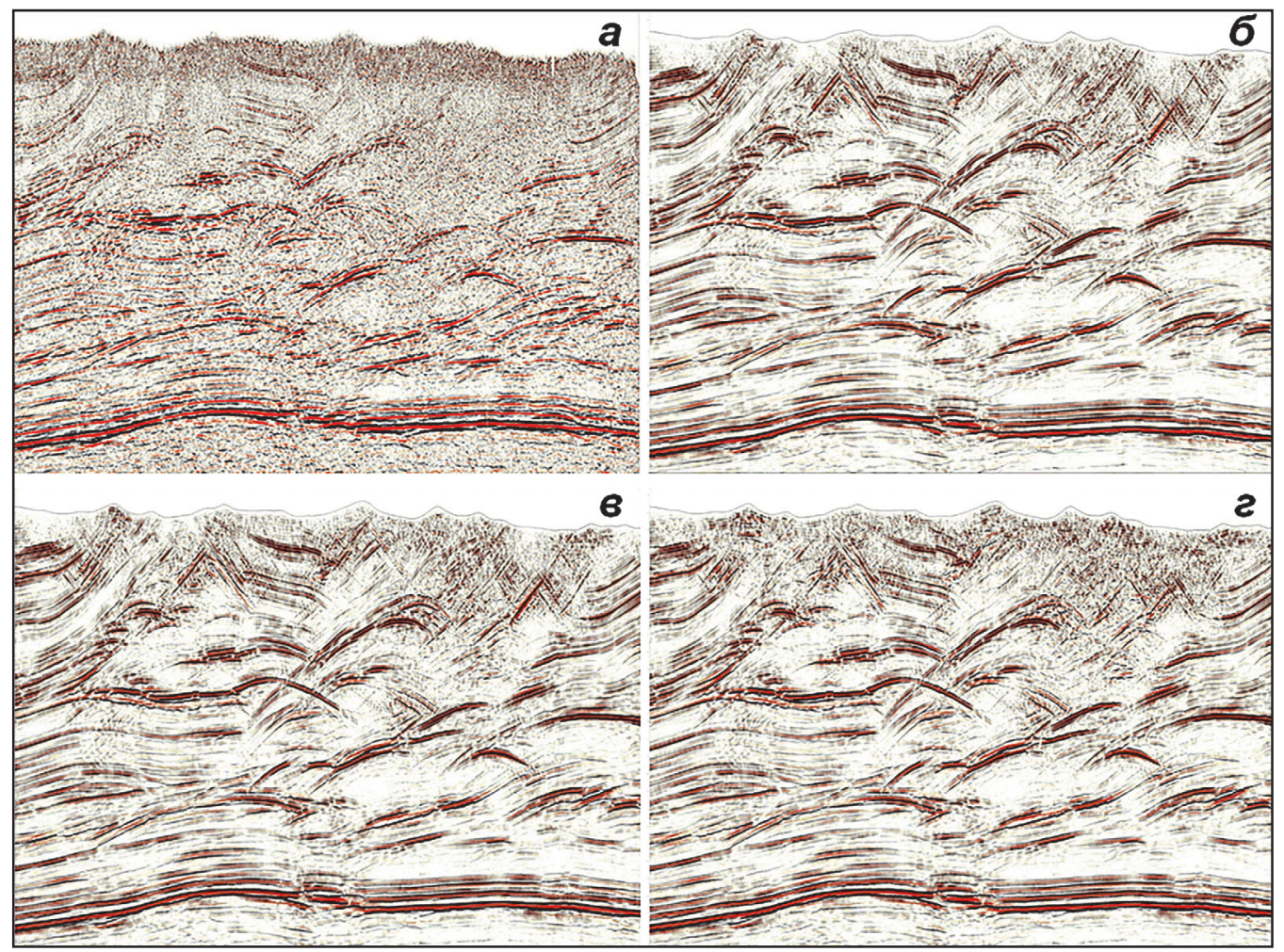

Рисунок 7 - Влияние на результаты МФ уменьшение кратности сейсмограмм ОГТ: a - разрез ОГТ $N=120$, разрезы МФ с кратностью: $6-N=120$, в $-N=60, z-N=30$ 
На мигрированном суммарном кубе МФ (рисунок 8, б) наблюдается значительное улучшение прослеживания отражающих горизонтов, по сравннию с кубом ОГТ (рисунок 8, а):

- опорных отражающих горизонтов по всей глубине разреза, включая верхний интервал накопления кратности ОГТ, а также под соляным куполом, причем без применения глубинной миграции до суммирования PSDM;

- энергетически слабых второстепенных отражений, выделение которых проблематично при стандартной обработке ОГТ. Эти отражения характеризуют внутреннее геологическое строение потенциально перспективных в отношении нефтегазносности надсолевого, соленосного и подсолевого осадочных комплексов;

- существенно изменилось изображение соляного купола, на котором уверенно выделился соляной карниз, что необходимо будет учесть при обработке PSDM.
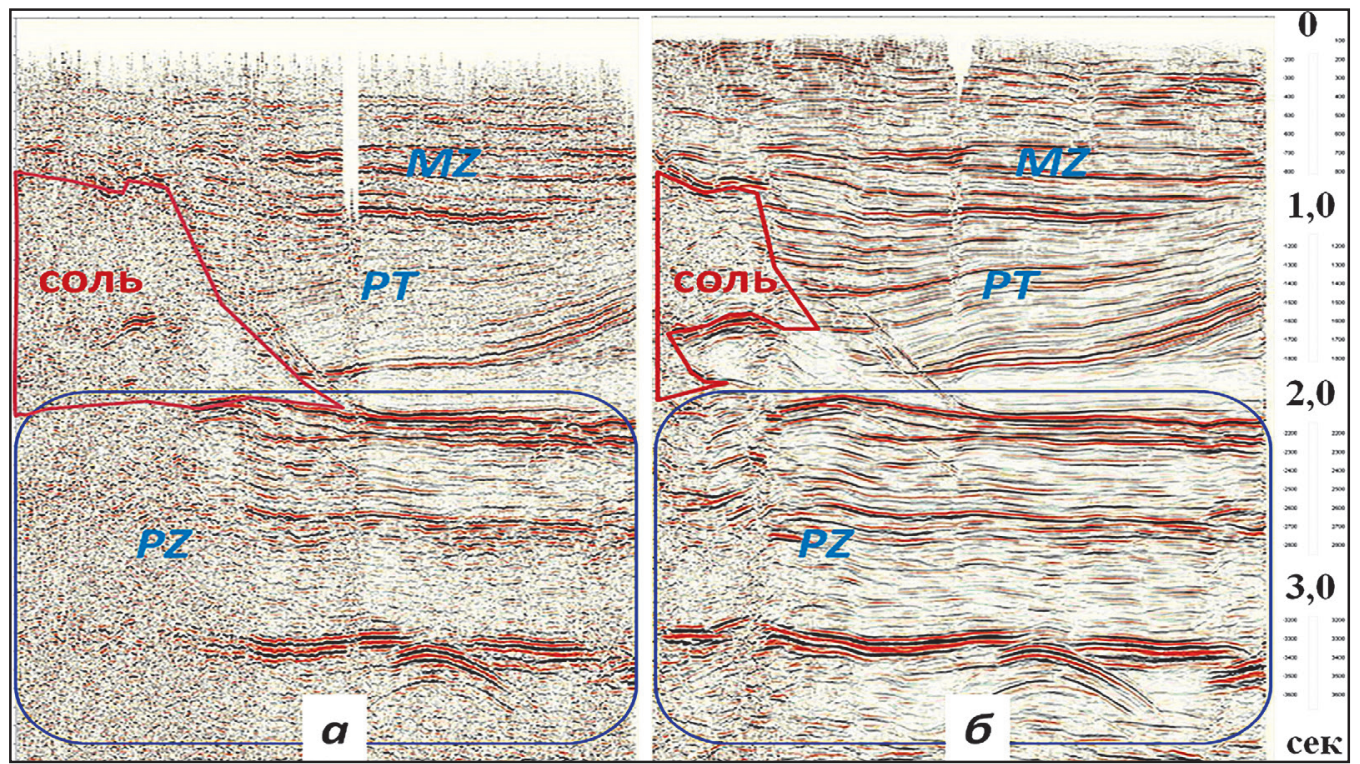

Рисунок 8 - Сравнение сечений Inline кубов PostSTM:

a - стандартная обработка ОГТ; б - с примением Мультифокусинга

Задачи разведки и детального изучения геологического строения неглубоко залегающих структур и ловушек нефти (глубина до 300-400 м) являются проблематичными на основе среднечастотной сейсморазведки ОГТ. Причинами низкого качества освещения верхней части разреза (ВЧР) на разрезах и кубах ОГТ являются: (1) интервал накопления кратности ОГТ от 1 до проектной; (2) большие интервалы между линиями возбуждения и приема, которые в 5-10 раз превышают шаги между пунктами возбуждения (ПВ) и приема (ПП). Верхние интервалы сейсмических разрезов ОГТ, полученных в Прикаспийской впадине (рисунок 9, 1, a, нефтяной резервуар на глубине 60-70 м) и в предгорьях Канады (рисунок 9, 2, a), практически не освещаются в поле отражениных волн. После применения технологии МФ качество сейсмических изображений в рассматриваемых интервалах существенно улучшилось (рисунок 9, б), в т.ч. за счет учета пересеченного рельефа поверхности наблюдений в предгоьях Канады (рисунок 9, 2, б). 
Латеральная разрешенность сейсмической записи на результатах МФ находится в зависимости от размера «супербазы», определяемого в процентах от размера 1-й зоны Френеля, который увеличивается с глубиной. При задании данного параметра МФ в пределах 1/3 от размера 1-й зоны Френеля получим оптимальный баланс между латеральной разрешенностью сейсмической записи и статистическим эффектом накапливания сигналов (кратность сейсмограммы МФ). На мигрированном разрезе МФ (рисунок 10, б), полученного по сейсмоданным морской сейсморазведки, демонстрируется улучшение качества прослеживании и разрешенности записи опорных и вспомогательных отражений в юрском и меловом комплексах. Отметим значительное повышение латеральной разрешенности в вертикальных зонах характерных изображений возможных «грязевого вулкана» (синие стрелки) и «газовых трубок» (синие стрелки) [18]. Некоторое ухудшение прослеживания отражений в интервале палеоген-неогеновых отложений связано с тем, что их динамическая выразительность много слабее на фоне отражения от дна моря (желтые стрелки).

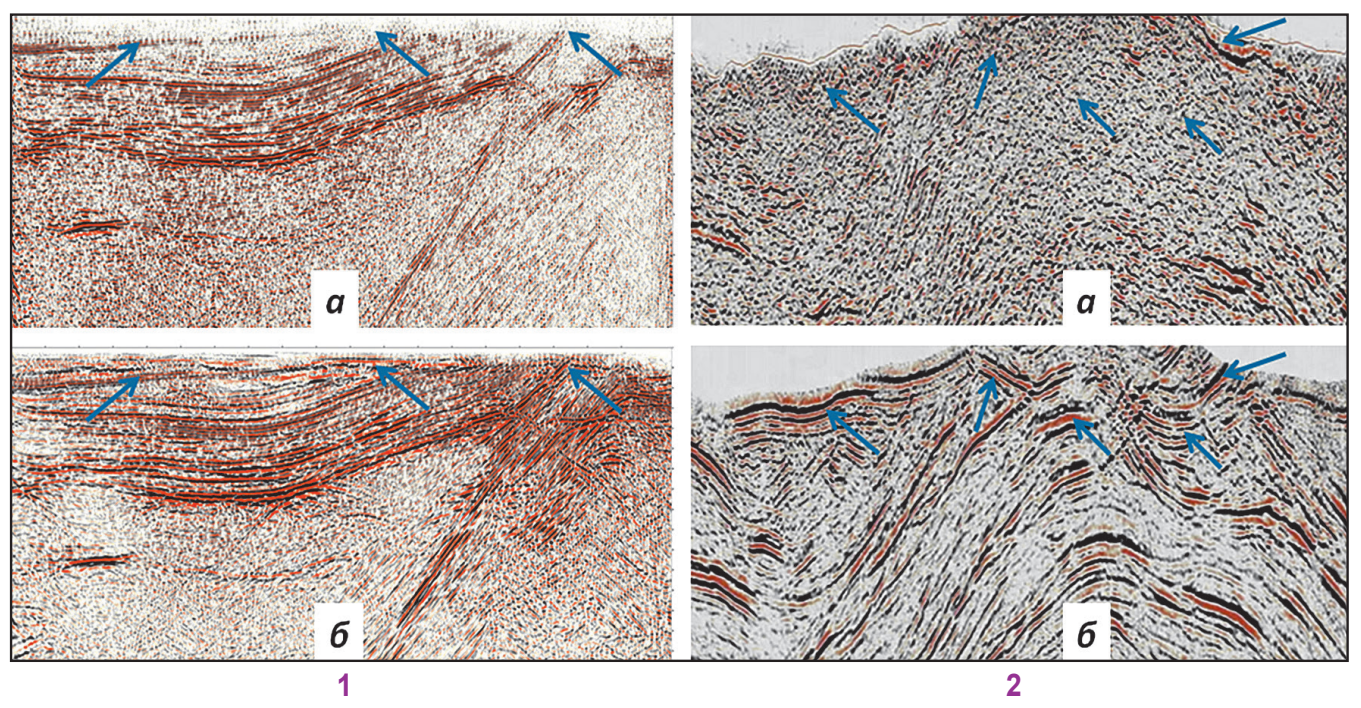

Рисунок 9 - Улучшение сейсмических изображений в ВЧР:

1 - условия Прикаспийской впадины; 2 - предгорье (провинция British Columbia, Канада)

a - суммарный разрез ОГТ; 6 - суммарный разрез МФ (из материалов «Geomage, LTD»)

Повышение эффективности технологии PSDM на основе результатов Мультифокусинга. В первой части статьи было отмечено, что эффективность PSDM существенным образом зависят от адекватности сформированной глубинно-скоростной модели (Модель PSDM) строению изучаемой среды $[12,13]$. Формирование начального приближения Модели PSDM выполняется по временному или мигрированному разрезу или кубу ОГТ, на которых прослеживание целевых отражающих горизонтов ухудшается вплоть до полной их потери, по мере усложнения строения геологического разреза и увеличения негиперболичности годографов отраженных волн. Если Модель PSDM будет содержать значимые погрешности геометризации границ раздела, тектонических нарушений и пластовых скоростей, то в процессе итеративной обработки PSDM минимизировать такие погрешности будет проблема- 


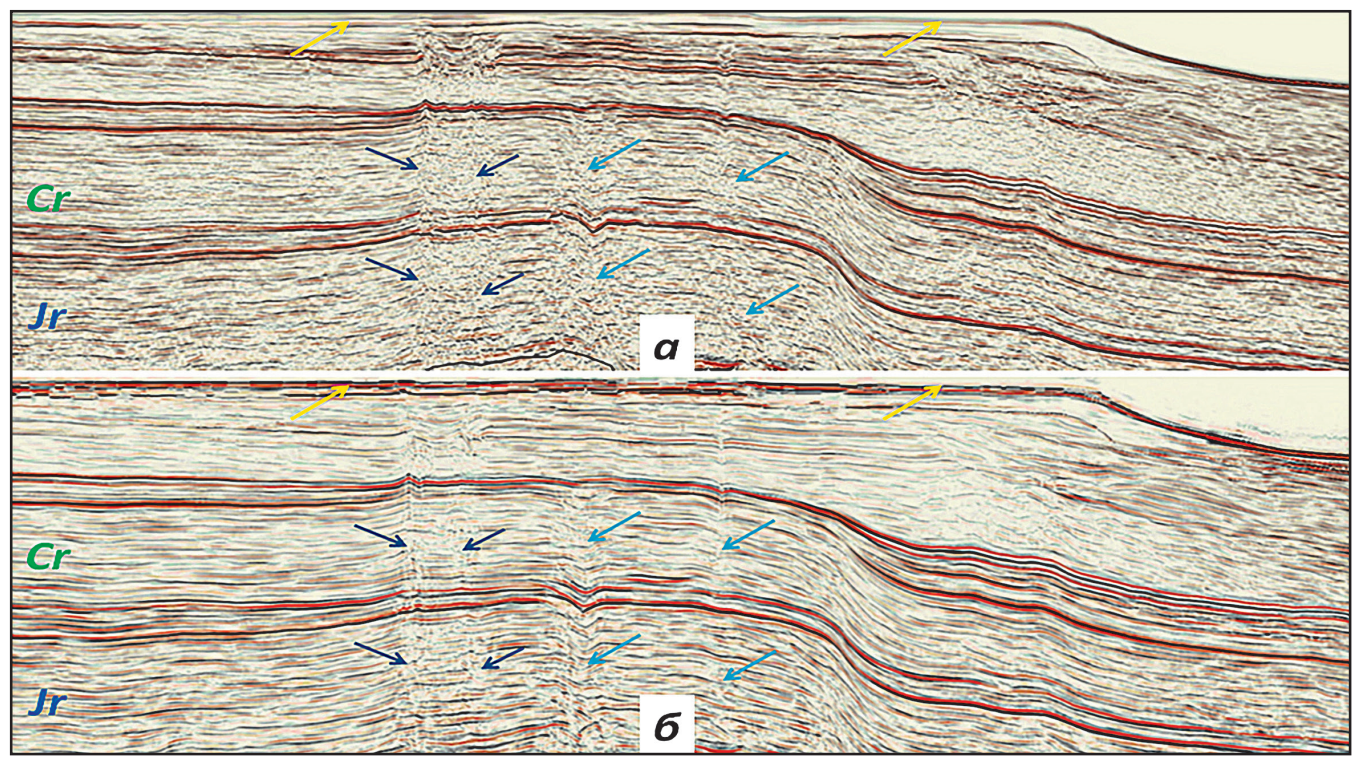

Рисунок 10 - Сравнение разрешенности записи на морских сейсмических разрезах: a - стандартная обработка ОГТ; б - с применением технологии Мультифокусинг

тично. На соответствующих участках результатов PSDM сейсмическое изображение среды также будет с искажениями или не содержать целевых отражений, что не обеспечит решение целевых геологических задач исследований.

Для существенного повышения качества сейсмических изображений на результативных разрезах и кубах PSDM рекомендуем: (1) формировать начальный вариант Модели PSDM по более полному и качественному сейсмическому изображению среды на разрезах или кубах МФ; (2) использовать в качестве входных данных PSDM улучшенные сейсмограммы МФ $[16,17]$. Отметим, что на результатах PSDM и PSTM, полученных по улучшенным сейсмограммам МФ, может наблюдаться некоторое уменьшение разрешенности записи в сравнении с суммарными или мигрированными разрезами и кубами МФ. Это связано с алгоритмом ввода кинематических поправок в технологиях миграции PSDM и PSTM, приводящему к растяжению сейсмической записи на удаленных трассах.

Использование улучшенных сейсмограмм МФ в качестве входных данных в технологии PSDM. На рисунке 11 сравниваются сейсмические изображения на кубах PSDM при стандартной глубинной миграции по сейсмограммам ОГТ и по улучшенным сейсмограммам МФ. Для чистоты эксперимента была использована одна и та же Модель PSDM. Использование улучшенных сейсмограмм МФ значительно улучшило сейсмическое изображение на кубе PSDM (рисунок 11, б), что демонстрируется на вертикальных сечениях и горизонтальном слайсе на уровне подсолевого опорного горизонта ПЗ . При этом количественные оценки С/П в среднем увеличились до 2-3 раз и разрешенность записи - до 10-15\%, по сравнению с результатом стандартной обработки $\operatorname{PSDM}($ рисунок 11, a).

Опция «Вычитание многократных волн-помех» в технологии Мультифокусинг реализована на основе: скоростного анализа атрибутов МФ, формирования 


\section{РАЗВЕДКА}

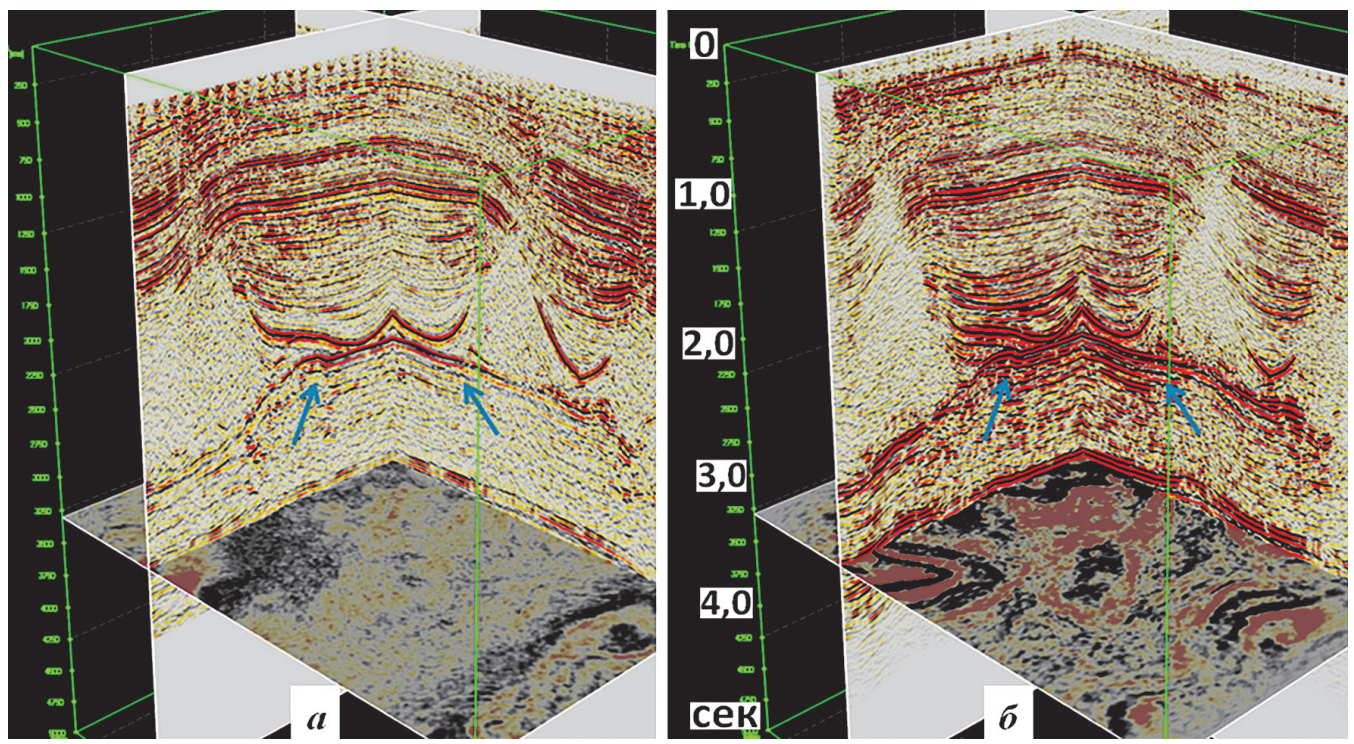

Рисунок 11 - Сравнение сечений кубов PSDM: a - предыдущая стандартная обработка; б - по улучшенным сейсмограммам МФ

модели многократных волн и процедуры адаптивного вычитания отфильтрованных предсказанных кратных волн из сейсмической записи на улучшенных сейсмограммах MФ [19]. Сейсмический разрез (предгорье Карпат, материалы «Rompetrol») получен в условиях слабой дифференциации акустических свойств осадочных отложений (рисунок 12). Поэтому на большей части суммарного разреза ОГТ, отражения плохо видны на фоне нерегулярной записи (рисунок 12, 1, a). На базовом разрезе МФ существенно улучшилось изображение однократных и кратных отраженных волн, имеющих близкие параметры МФ (рисунок 12, 1, б). Сейсмическое изображение разреза заметно изменилось после применения опции «Вычитание многократных волн-помех» (рисунок 12, 1, в), но определить достоверность этого разреза можно будет при наличии данных ВСП. В другом примере (из материалов «Geomage, LTD») кратные волн энергетически значительно сильнее однократных отраженных волн, которых практически не видно в нижней части базового разреза МФ (рисунок 12, 2, б). Применение опции «Вычитание многократных волн-помех», по оценке заказчика, привело к получению более реалистичного изображения нижнего структурного этажа (рисунок 12, 2, в).

Применение «глубинной миграции после суммирования» по сумарному кубу МФ (обозначим PostSDM+MФ) рассмотривается как методический прием повышающий эффективность технологии PSDM. В ряде случаев куб PostSDM+MФ может стать альтернативным результатом глубинной миграции. В представленном примере на рисунке 13 сравниваются изображения на стандартном кубе PSDM и кубе PostSDM+MФ, полученных с использованием одной и той же Модели PSDM (из материалов TOO «Казахойл Актобе»). На кубе PostSDM+МФ наблюдается значительное улучшение (рисунок 13, б): 


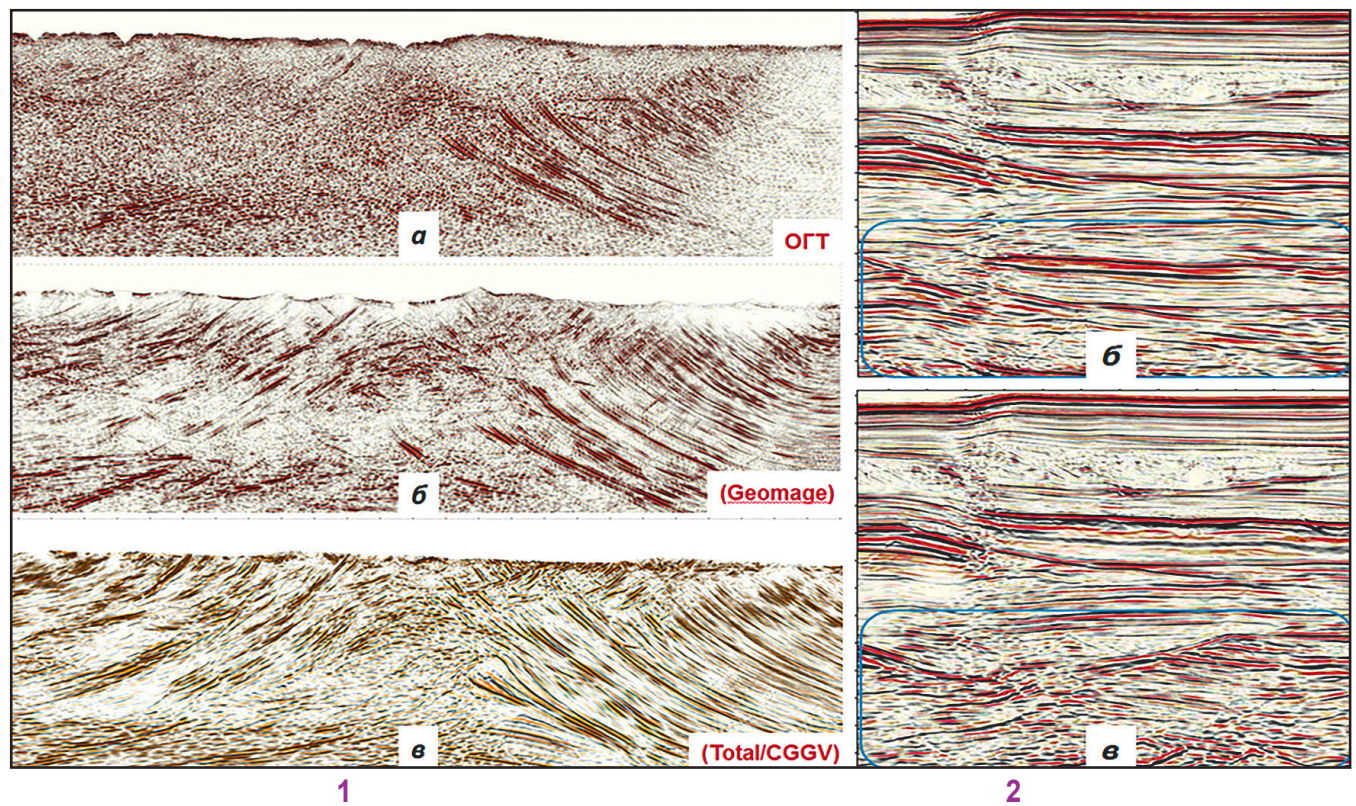

Рисунок 12 - Сравнение вариантов суммарных разрезов: 1 - однократные и кратные волн имеют близкие параметры МФ; 2 - энергия однократных волн существенно меньше, чем у кратных волн; а - стандартная обработка ОГТ; б - базовое суммирование МФ; в - после вычитания кратных волн на улучшенных сейсмограммам МФ

- качества прослеживания основных и второстепенных отражающих горизонтов по всей глубине разреза;

- изображения блокового строения подсолевого карбонатного нефтяного месторождения;

- разрешенности записи и детальность изображения внутреннего строения продуктивного интервала каменноугольного комплекса отложений;

- изображения соляного купола, которое трансформировалось из трапецивидной формы на кубе PSDM (рисунок 13, а) в грибовидную на кубе PostSDM+MФ (рисунок 13, б).

На кубе PSDM, представляемом в глубином масштабе, сейсмическая запись с глубиной становится все более низкочастотной. Для повышения надежности прослеживания отражающих горизонтов могут применять полосовую фильтрацию или частотно-зависимые процедуры. Указанное приводит к ухудшению разрешенности записи, что может сделать невозможным изучение внутреннего строения перспективного подсолевого комплекса отложений (оранжевые стрелки на рисунке 13, a).

Применение опции «Мультифокусинг после суммирования» существенно повышает качество сейсмических разрезов «старых» сейсмических профилей, отработанных более 30 лет назад. По этим профилям в фондах сохранились суммарные или мигрированные сейсмические временные разрезы ОГТ на бумаге (фотобумаге). За давностью лет трудно рассчитывать на сохранность «старых» суммарных разрезов ОГТ и полевых сейсмический записей в электронном (цифровом) виде на магнитных носителях с тем, чтобы без потери информации их переобработать и выполнить переинтерпретацию. Практические результаты оцифровки с фотобумаги в стандартный формат SEGY суммарных разрезов ОГТ (около 3000 пог. км) и вы-

$$
\text { НЕФТЬ И ГАЗ } 20212 \text { (122) }
$$




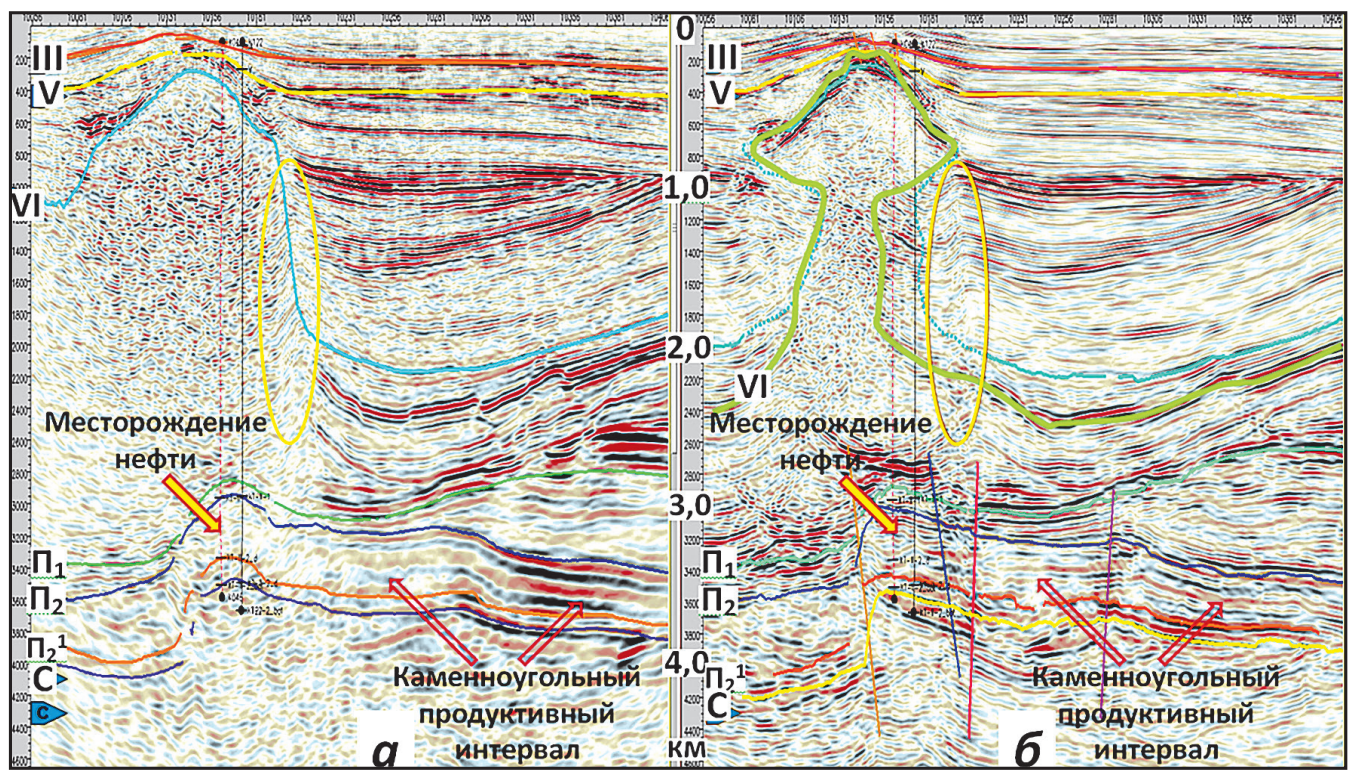

Рисунок 13 - Сравение сечений кубов: а -стандартная обработка PSDM, б - глубинная миграция PostSDM суммарного куба МФ

полнения постобработки показывают, что качество восстановленных сейсмических разрезов ОГТ близко к оригиналам на фотобумаге или немного лучше.

На результатах «Мультифокусинг после суммирования» существенно повышается (до 2-3 раз по количественным оценкам С/П) качество сейсмического изображения на восстановленных или сохранившихся в электронном виде «старых» сейсмических разрезах или кубах ОГТ (рисунок 14). На таких улучшенных изображениях среды и прослеживания опорных и второстепенных отражающих горизонтов могут быть выявлены новые структурные и неструктурные перспективные ловушки УВ, которые ранее не были обнаружены на «старых» сейсмических разрезах. Отметим, что также на результатх «Мультифокусинга после суммирования» будет улучшено выделение тех волн-помех, которые не были удалены в процессе прежней обработки.

Данный пример и другие результаты подтверждают эффективность «Мультифокусинга после суммирования». Применение данной опции улучшит сейсмическое изображение среды, т.е. повысит геологическую информативность данных сейсморазведки прошлых лет, которая также повысит коммерческую привлекательность малоизученных территорий и будет полезна в действующих проектах разведки.

Аналогичные работы по оцифровке и восстановлению сейсмических разрезов ОГТ прошлых лет описаны в статье [20], где также предполагается возможность выполнения «динамического» анализа по восстановленной сейсмической записи. Но будут ли эти результаты иметь высокий коэффициент корреляции со скважинными данными?

Известные положительные результаты «динамического» анализа данных 3 Д и 4Д сейсморазведки были получены в благоприятных сейсмогеологических условиях и при применении современных методик и технологий полевой сейсмосъемки. Во 


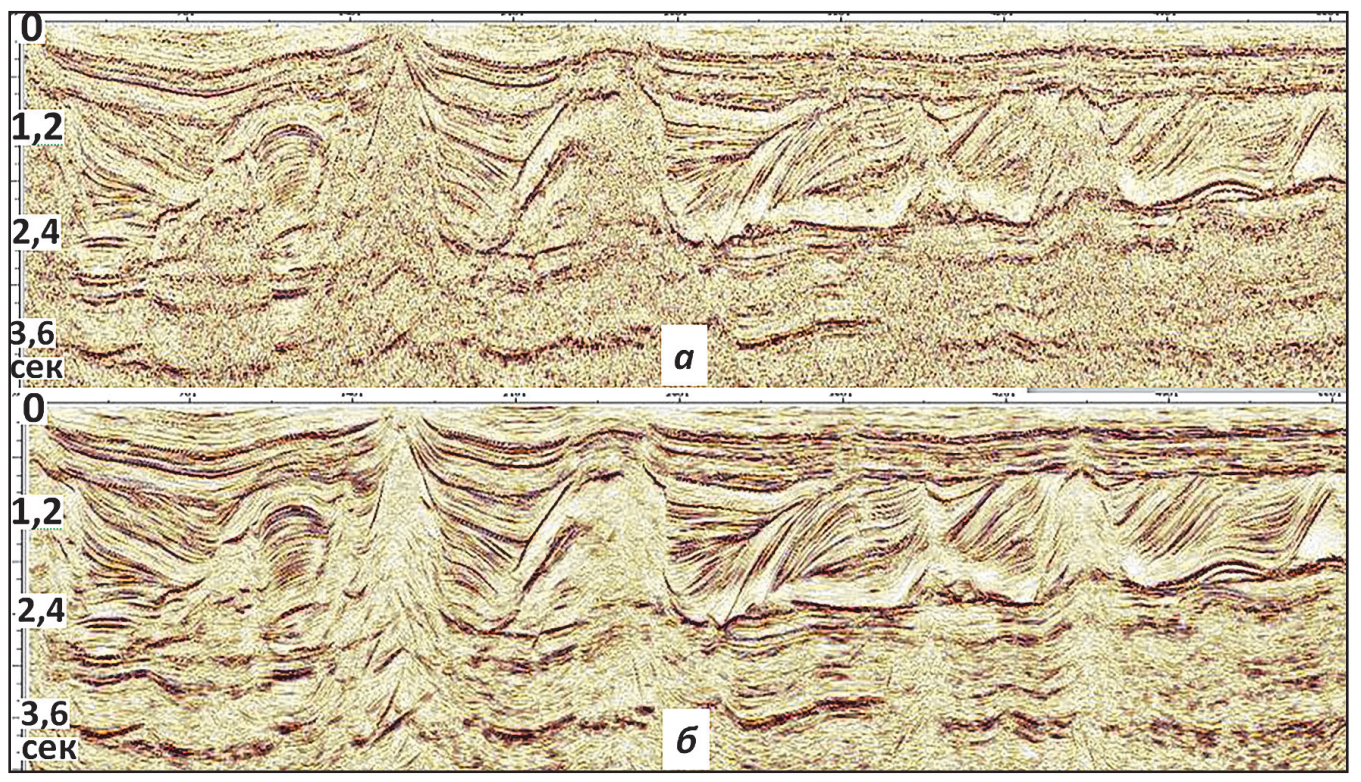

\section{Рисунок 14 - Улучшение сейсмического изображения восстановленного сейсмического профиля: a - сейсмический разрез ОГТ; б - с примением «Мультифокусинга после суммирования}

многих других случаях проблематично обеспечить требования к качеству сейсмических записей даже при применении самых современных технологий полевых сейсмосъемок и последующей цифровой обработки. Отметим, что в настоящей статье делается акцент на том, что для реального повышения достоверности результатов «динамического» анализа необходимо иметь соответствующие соотношение Сигнал/Помеха и разрешающую способность на записях до и после суммирования (миграции). Этим требованиям вряд ли отвечают данные 2Д сейсморазведки прошлых лет с кратностью ОГТ $N=12,24$.

Таким образом, эффективность технологии Мультифокусинг наглядно показана на приведенных примерах (рисунок 8-14), полученных по 2Д/3Д сейсмоданным в разных сейсмогеологических условиях и по разным методикам полевой сейсмосъемки. Совокупность отличительных свойств МФ обеспечивает существенное улучшение качества и разрешенности сейсмических изображений по всей глубине разрезов МФ: (1) при пониженной кратности исходных сейсмограмм ОГТ, в т.ч. в верхней части разреза; (2) при вычитании кратных волн, которые не были подавлены при стандартной обработке по методике ОГТ; (3) на восстановленных суммарных разрезах ОГТ. Кроме того, на основе результатов МФ, включая улучшенные сейсмограммы МФ, значительно повышается эффективность и достоверность результатов технологии глубинной миграции до (PSDM) и после суммирования (PostSDM).

\section{КАЧЕСТВО СЕЙСМИЧЕСКОГО ИЗОБРАЖЕНИЯ СРЕДЫ И РАСШИРЕНИЕ КРУГА ГЕОЛОГИЧЕСКИХ ЗАДАЧ}

Все более актуальными становятся задачи выявления неантиклинальных (неструктурных) ловушек в нефтегазоносных бассейнах, которые разделяют по типам 
ловушек, генетическим группам и формирующим процессам и с которыми связывают прирост углеводородного потенциала $[21,22,23]$. Также возрастает внимание к изучению геологического строения и оценки перспектив нефтегазоносности глубоко залегающих палеозойских отложений в Западной Сибири, Прикаспийской впадине и других осадочных бассейнах [23, 24, 25, 26 и др.]. Достоверность решения геологических задач разведки и доразведки месторождений УВ во многом зависит от качества сейсмического изображения среды на результатах сейсморазведки методом ОГТ в поле отраженных волн и от достоверности скоростной модели среды, формируемой по опорным скважинным данным (ГИС и ВСП). Выявление неантиклинальных ловушек выполняют по характерным особенностям рисунков сейсмического изображения на основе знаний петрофизических свойств пород, условий осадконакопления и другой геологической информации об изучаемых комплексах отложений $[6,27]$.

Для повышения эффективности разведки структурных и неструктурных ловушек УВ применяют комплексный анализ полей отраженных волн, формирующихся на протяженных границах раздела, и дифрагированных волн, которые образуются на локальных геологических объектах и разномасштабных акустических неоднородностях: контактах слоев с разломами или с другими слоями, в зонах трещиноватости, каверно- или карстообразования и пр. В данной статье приведены примеры существенного повышения качества сейсмического изображения среды при применении технологий «Мультифокусинг» и «Дифракционный Мультифокусинг» (ДМФ). Преимуществом технологии ДМФ перед альтернативными технологиями является то, что фокусирование энергетически слабых дифрагированных волн основано на использовании улучшенных сейсмограммам МФ и параметров МФ, включая учет негиперболичности годографов в условиях сложнопостроенных сред, которые были полученны в результате базовой обработки МФ. На результатах ДМФ дифрагированные волны представляются в виде локальных амплитудных аномалий (аномалии ДМФ), которые показывают на наличие в разрезе локальных акустических неоднородностей [14, 28, 29, 30].

Выявление структурных и неантиклинальных ловушек УВ в Прикаспийской впадины. В статье [23] рассмотрены примеры крупных седиментационных структур карбонатного (массивы) и терригенного (конуса выноса) состава, а также седиментационно-эрозионные типы ловушек в глубоко залегающих подсолевых палеозойских отложениях. Выявление этих ловушек на удовлетворительного качества сейсмических разрезах следует отнести к геологической интерпретации, основанной на большом опыте, знаниях и интуиции геологов. Применение технологии Мультифокусинг существенно повышает качество и детальность сейсмического изображения среды, следовательно, и достоверность выявления глубоко залегающих перспективных палеозойских структур и объектов [27, 30].

Как уже отмечалось, изучение внутреннего строения подсолевого палеозойского комплекса отложений, в котором слои характеризуются незначительной акустической дифференциацией, осложнено в поле нерегулярных и динамически слабых второстепенных отражений на результатах метода ОГТ. Так, на глубинном разрезе предыдущей обработки PSDM (рuс. 15, a) в интервале девонских отложений наблюдаются лишь 


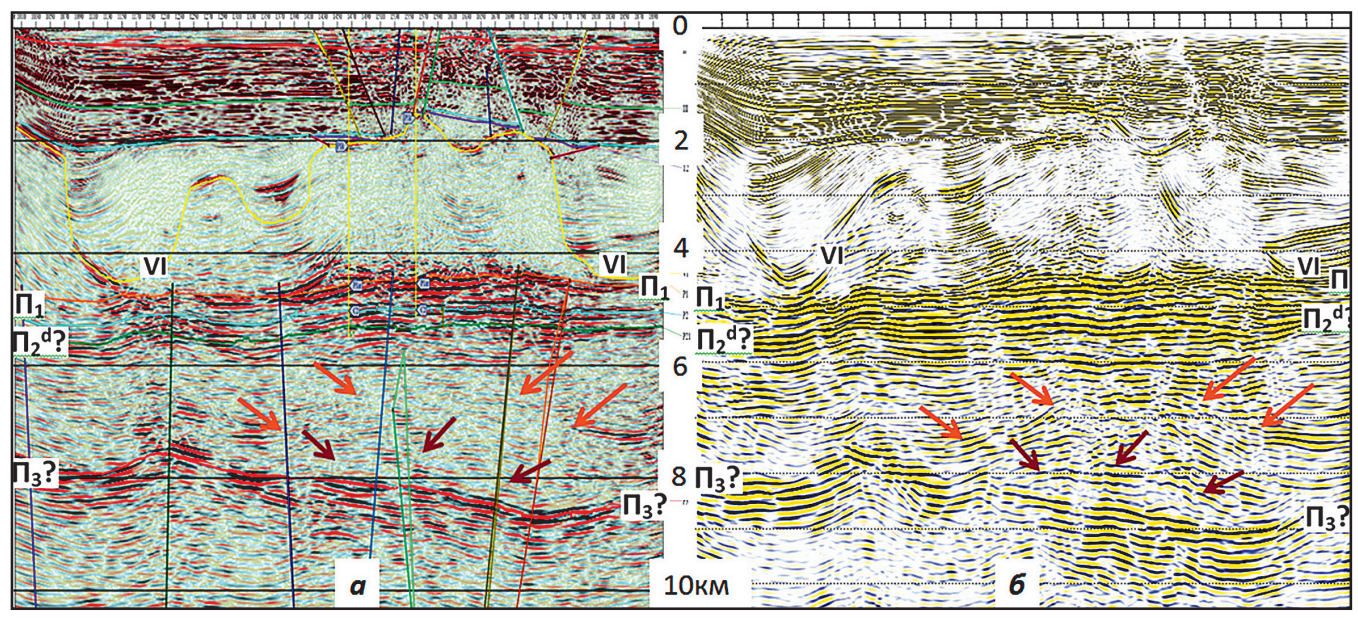

Рисунок 15 - Выделение антиклинального объекта в подсолевом палеозойском комплексе отложений: a - предыдущая обработка; б - с применением Мультифокусинга

отдельные отражающие площадки, по которым невозможно судить об особенностях строения девонских отложений. Использование улучшенных сейсмограмм МФ значительно повысило качество сейсмического изображения по всей глубине разреза PSDM (рисунок 15, б), включая подсолевой комплекс отложений. В интервале девонского комплекса отложений достаточно уверенно стал выделяться антиклинальный объект, оконтуренный энергетически слабыми отраженными волнами (оранжевые и коричневые стрелки на рисунок 15, б), которые имеют характерные угловые несогласия с опорными отражающими горизонтами $\Pi_{2}{ }^{\mathrm{d}}$ ? и $\Pi_{3}$ ? и отражающими площадками в рассматриваемом довонском интервале разреза. Данный объект также был виден на других сейсмических профилях, имеющих разные азимуты.

Другие примеры выделения антиклинальных объектов в подсолевом палеозойском комплексе отложений приведены на сечениях кубов PSDM, полученных с использованием улучшенных сейсмограммм МФ (рисунок 16). Выравнивание отражающего горизонта $\Pi_{2}{ }^{\mathrm{C}}$ ? сделало более выразительным актиклинальный объект в каменноугольных отложениях (рисунок 16, a). Изображения рисунков выделенных (синим контуром) объектов в каменноугольных и девонских отложениях заметно отличаются по ослаблению динамики записи от вмещающих отложений и угловыми несогласиями отражений на склонах и внутри этих объектов. Отметим, что на этих примерах не все отражения от склонов могли быть зарегистрированы из-за ограниченной площади 3 Д сейсмосъемки и большой глубины залегания рассматриваемых палеозойских отложений.

Качество сейсмического изображения на мигрированном разрезе PostSTM, полученного с использованием улучшенных сейсмограмм MФ (рисунок 17, б), значительно лучше по всей глубине разреза, чем на разрезе PostSTM предыдущей обработки (рисунок 17, a). При этом повысилось качество прослеживания отражений от кровли соляного купола и соляного карниза, пермотриасовых и подсолевых отражающих горизонтов, второстепенных отражений в толще юрских и пермотриасовых отложений. Отметим улучшение выделения следующих неантиклинальных ловушек (рисунок 17): 


\section{РАЗВЕДКА}

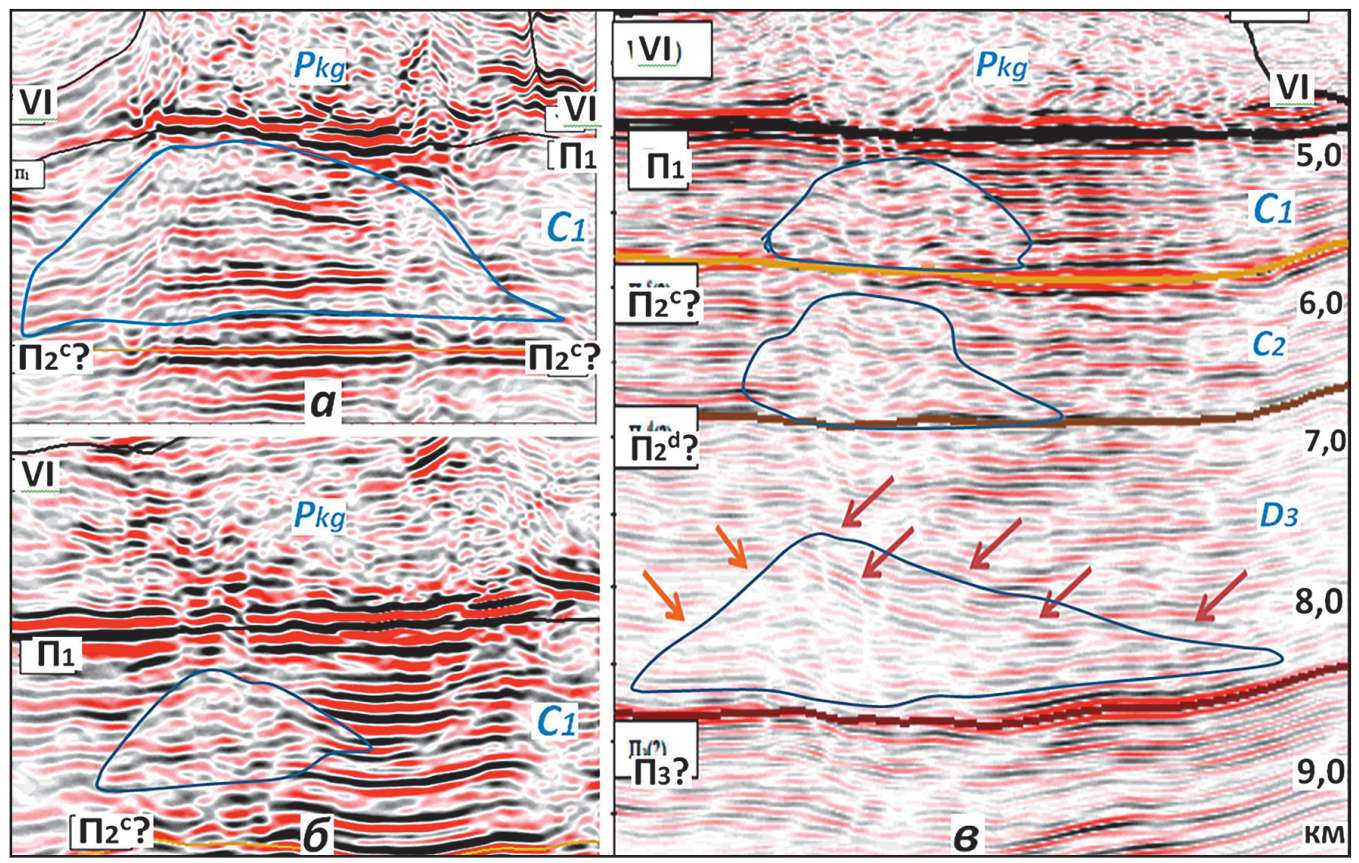

Рисунок 16 - Примеры выделения рифоподобных объектов на кубах PSDM+МФ: а, б - в верхнем карбоне; в - в верхнем карбоне и девоне

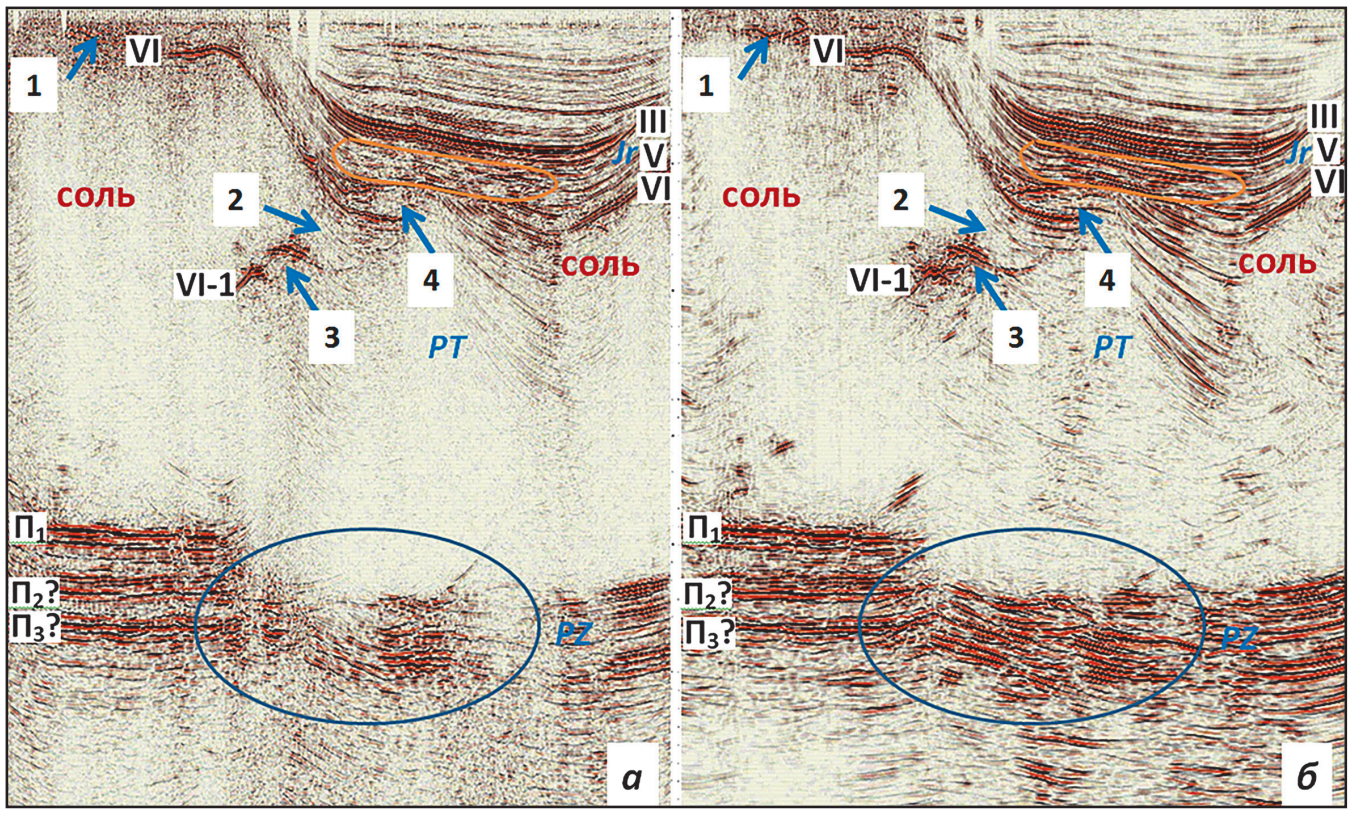

Рисунок 17 - Выделение неантиклинальных ловушек на разрезах 2Д PostSTM: a - стандартная обработка, б - с применением Мультифокусинга;

1 - кровля соляного купола, 2 - соляной карниз, 3 - подкарнизная ловушка, 4 - рифоподобный объект в триасе 
1) Локальное увеличение динамической выразительности записи на второстепенных отражениях (в оранжевом контуре) внутри толщи юрского комплекса может свидетельствовать о наличии литологической ловушки с повышенной песчанистостью;

2) Под соляным карнизом была выявлена продуктивная нефтяная залежь;

3) В интервале верхнетриасовых отложений выделился рифоподобный объект.

В условиях трехмерных сред 3Д сейсморазведка значительно повышает качество результатов обработки сейсмоданных. На кубе PSDM, полученного с использованием улучшенных сейсмограмм МФ, существенно повысилось качество сейсмического изображения по всей глубине разреза, при этом выделилось многослойное подкарнизное месторождение нефти в поле отраженных волн (рисунок18, б), строение которого было проблематично определить на стандартном кубе PSDM (рисунок 18, $a$ ). На сечениях этих кубов PSDM вдоль подкарнизных отражений видно только одно амплитудное тектоническое нарушение. Дальнейшая обработка улучшенных сейсмограмм по технологии 3Д «Дифракционный Мультифокусинг» выделила локальные амплитудные аномалии дифрагированных волн (ДМФ), согласованный характер которых в интервале подкарнизной пермотриасовой залежи свидетельствует о наличии серии малоамплитудных тектонических нарушений (рисунок 18, в). На других участках применение МФ также повысило качество выделения отражений в подкарнизном интервале. Более широкое применение МФ в новых или существующих сейсморазведочных проектах приведет к увеличению количества выделяемых покарнизных ловушек и детальности изучения их геологического строения.

Анализ совмещенных изображений кубов МФ (поле отраженных волн) и ДМФ (поле дифрагированных волн) (рисунок 19, a) и карты амплитудных аномалий ДМФ (рисунок 19, б), сформированной из в подсолевом интервале продуктивной карбонатной толщи, показывает, что аномалии ДМФ имеют высокую разрешенность и амплитудную дифференциацию. Наблюдается приуроченность аномалий ДМФ к: тектоническим нарушениям; отдельным отражающим горизонтам; зонам интенсивной трещиноватости, определнной по данным FMI и керну. При сопоставлении аномалий

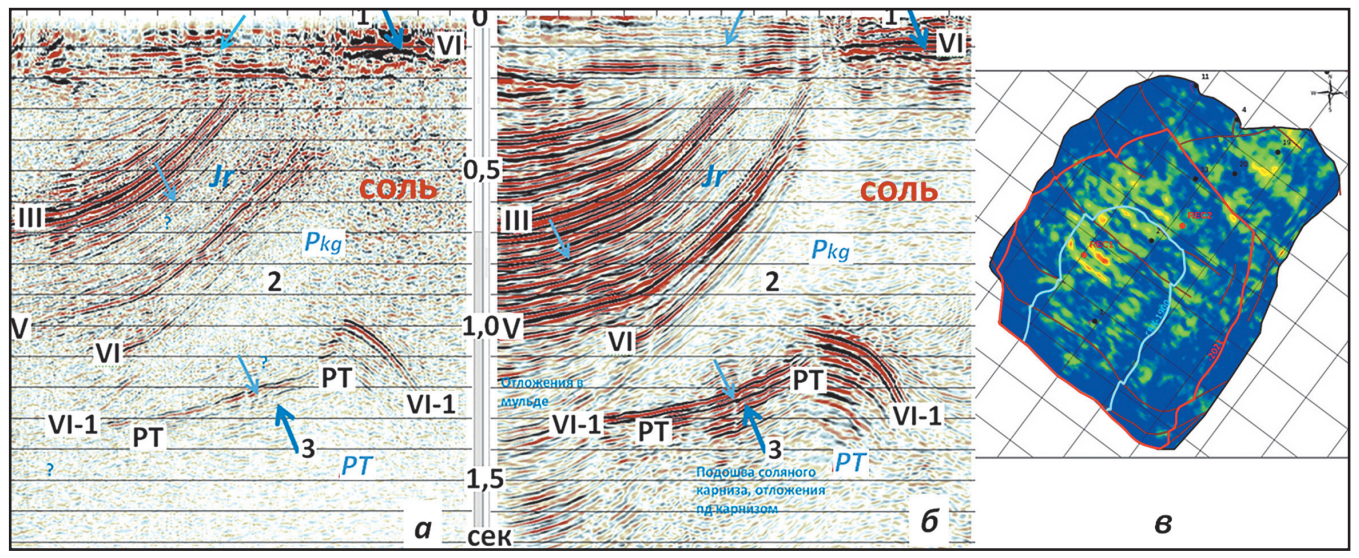

Рисунок 18 - Выделение подкарнизной многопластовой ловушки на кубах PSDM:

a - стандартная обработка, б - с применением Мультифокусинга, в - карта атрибута ДМФ; 1 - кровля соляного купола, 2 - соляной карниз, 3 - подкарнизная ловушка в триасе 


\section{РАЗВЕДКА}

ДМФ и дебитов в эксплуатационных скважинах (рисунок 19, в) был получен достаточно высокий коэффициент корреляции 0,65. Это дает основание рекомендовать корректировку схемы бурения эксплуатацоных скважин, с учетом местоположения аномалий ДМФ.
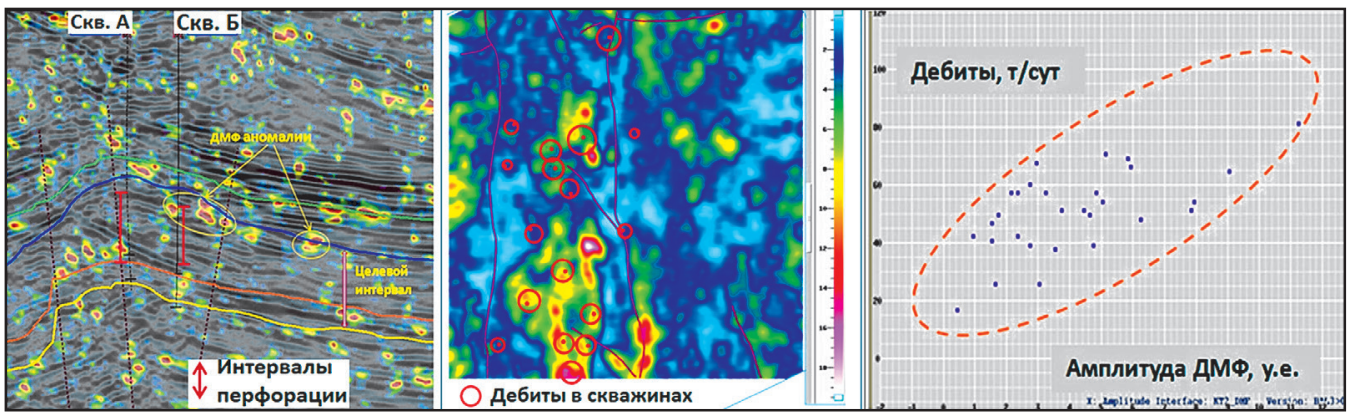

Рисунок 19 - Совместный анализ аномалий ДМФ: а - с полем отраженных волн, 6 - на карте амплитуд ДМФ в продуктивном интервале, в - с дебитами в эксплуатационных скважинах

При изучении баженовской свиты на месторождении нефти в Западной Сибири был получен более высокий коэффициент корреляции $(0,72)$ аномалий ДМФ с дебитами нефти в эксплуатационных скважинах в результате совместного анализ полей отраженных и дифрагированных волн [31].

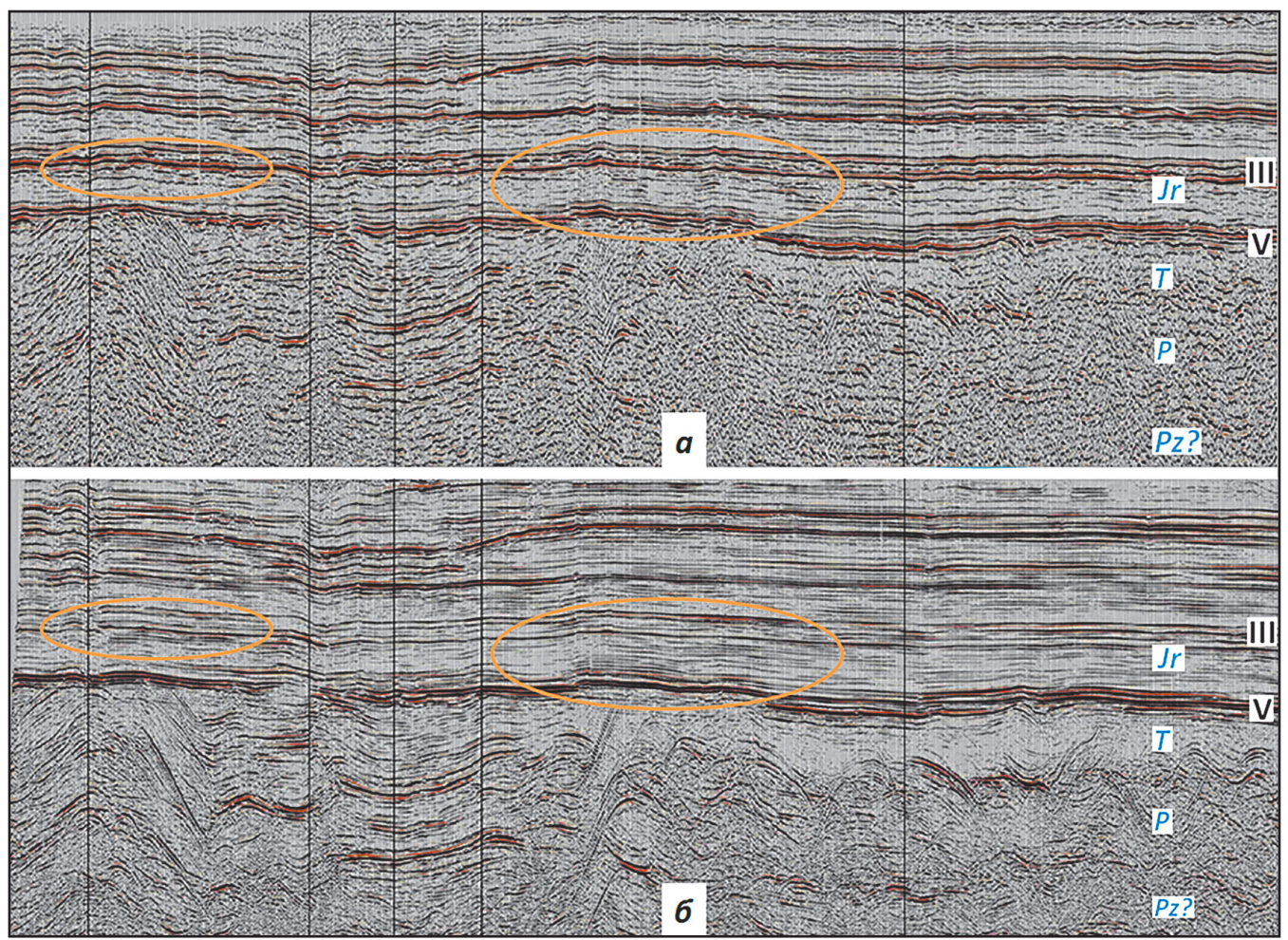

Рисунок 20 - Выделение литологических ловушек в юре и уточнение структурно-тектонического строения доюрских отложений (из материалов «Geomage LTD»): a - стандартная обработка ОГТ, б - с применением Мультифокусинга 
Сейсмические разрезы, приведенные на рисунках 20 и 21, были получены в Западной Сибири с целью разведки структур в перспективном юрском комплексе отложений. После дополнительной обработки сейсмограмм ОГТ по технологии Мультифокусинг значительно улушилось качество прослеживания основных и второстепенных отражений в юрско-меловых отложениях. На второстепенных отражениях в толще юрских отложений (оранжевые контуры на рисунках 20, б и 21, б) появились амплитудные аномалии, которые несколько смещены в пределах антиклинальных структур по горизонту III, что может свидетельствовать на наличии ловушек руслового или озерно-болотного типов.

Также необходимо отметить значительное улучшение сейсмического изображения доюрских отложений (рисунок 20 и 21), к которым в последние годы привлечено повышенное внимание с целью изучения перспектив нефтегазоносности [24, 28 и др.].

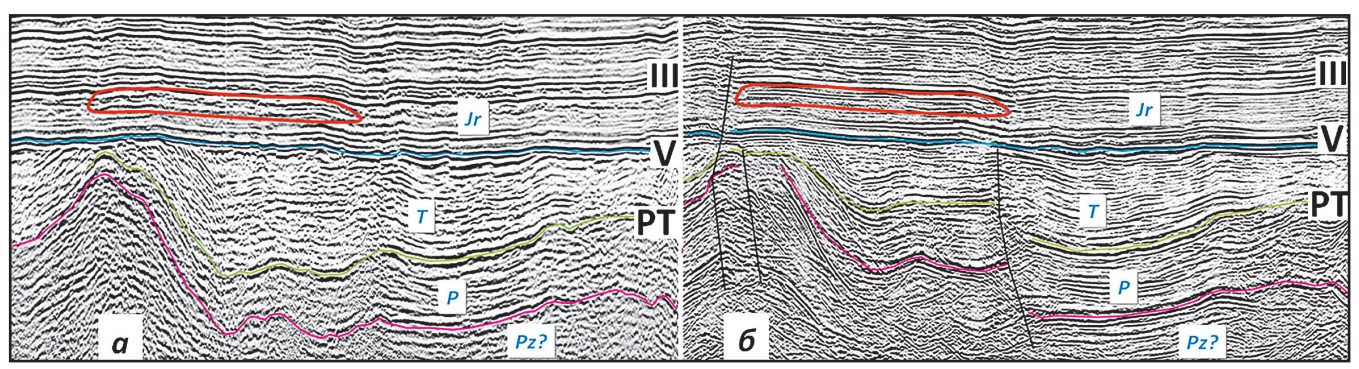

Рисунок 20 - Уточнение структурно-тектонического строения доюрских отложений (из материалов «Geomage LTD»): a - стандартная обработка ОГT, б - с применением Мультифокусинга

\section{ВЫВОДЫ И РЕКОМЕНДАЦИИ}

1. Для решения все более усложняющихся целевых геологических задач необходимо применять наиболее эффективные сейсморазведочные методики и технологии, в основе которых лежат математические модели среды адекватные реальному геологическому строению среды.

2. Применение технологии Мультифокусинг обеспечивает значительное повышение качества сейсмического изображения среды и сейсмической записи на улучшенных сейсмограммах МФ, с сохранением относительных амплитуд. Это расширяет круг решаемых геологических задач в разных сейсмогеологических условиях, включая задачи разведки мелких и глубоко залегающих структурных и неантиклинальных ловушек УВ, в т.ч. на основе выделенных энергетически слабых второстепенных отражений, а также при прогнозировании вещественного состава отложений и параметров коллектороских свойств отложений и покрышек. На этой основе будут повышены информативность и достоверность смежных видов сейсмогеологических исследований, уменьшены неопределенности параметров в геологических и гидродинамических моделях резервуаров и снижены риски разведочного и эксплуатационного бурения.

3. Опция «Мультифокусинг после суммирования» существенно повышает качество сейсмических разрезов на ретроспективных сейсмических профилях, которые 
были восстановлены (оцифрованы с бумаги) или сохранились в цифровом виде на магнитных носителях.

4. Повышение эффективности технологии глубинной миграции до суммирования (PSDM) связано с использованием результативных разрезов или кубов МФ и улучшенных сейсмограмм МФ. Также глубинный разрез или куб (PostSDM+MФ), полученный по сумарному разрезу или кубу МФ, может рассмотриваться как методический прием, повышающий эффективность технологии PSDM или как альтернативный результат глубинной миграции.

5. Относительная дороговизна инновационных сейсморазведочных методик и технологий сдерживает их широкое внедрение. Применение методики сверхплотной широкоазимутальной полевой 3 Д сейсморазведки повысит статистический эффект суммирования сигналов от 3-5 до 7-9 раз, в сравнении со стандартными проектами сейсморазведки и при кратном увеличении стоимости полевых сейсморазведочных проектов. Известно, что стоимость проектов сейсморазведки сопоставима со стоимостью одной разведочной скважины.

6. Применение обрабатывающих технологий Мультифокусинг и Дифракционный Мультифокусинг увеличит общую стоимость сейсморазведочного проекта до 10-20\%. Рассчетные оценки показывают, что применение МФ приводит к повышению качества сейсмического изображения среды за счет увеличения статистического эффекта суммирования сигналов от 5-7 раз в верхней и до 12-15 раз в нижней частях разреза, в сравнении с результатами стандартной обработки сейсмоданных по методике ОГТ. При этом количественные оценки соотношения Сигнал/Помеха увеличиваются в среднем до 2-3 раз и более, а разрешенность записи - до 10-15\%.

Для более объективной оценки повышения эффективности проектов сейсморазведки за счет усложнения полевой технологии сейсмосъемки и/или применения обрабатывающей технологии Мультифокусинг необходимо выполнить специальные исследования.

7. Применение методики морской высокоразрешающей сейсморазведки обеспечит повышение детальности изучения тонкослоистого разреза юрско-мелового и триасового комплексов отложений на шельфе Каспийского моря.

\section{ЛИТЕРАТУРА}

1 Исенов С.М. Проблемные вопросы и пути повышения эффективности сейсморазведки (при разведке и доразведке месторождений нефти и газа. / Нефть и газ. - 2021. № 1. - C. 52-68. [S.M. Issenov Problem Issues and Ways of Increasing the Efficiency of Seismic Research. / Oil and gas. - 2021. - No. 1. - PP. 52-68].

2 Бляс Э.А. Линеаризированный подход к определению импедансов продольных и поперечных волн по сейсмограммам отраженных волн (AVO-инверсия). / Технологии сейсморазведки, ЕАГО. - 2005. - № 1. - С. 5-15. [Blyas E.A. Linearized approach to the determination of $\mathrm{P}$ - and S-wave impedances from reflected wave seismograms (AVO inversion). / Technologies of seismic exploration, EAGO. - 2005. - No. 1. - PP. 5-15].

3 Ампилов Ю.П. От сейсмической интерпретации к моделированию и оценке месторождений нефти и газа. / - М., ООО «Издательство «Спектр». 2008, - 384 с. [Ampilov Yu.P. From seismic interpretation to modeling and appraisal of oil and gas fields. / - M., LLC "Publishing house "Spectrum". 2008. - 384 s.]. 
4 Мешбей В.И. Методика многократных перекрытий в сейсморазведке. / - М.: Недра. 1985. - 264 c. [ Meshbei V.I. Multiple overlap technique in seismic exploration. / - M.: Nedra, - 1985. - 264 s.].

5 Гогоненков Г.Н. Прогнозирование геологического разреза по сейсмическим данным. / Геология нефти и газа. - 1981. - № 1. - С. 48-55. [Gogonenkov G.N. Forecasting a geological section based on seismic data. / Geology of oil and gas. - 1981. - No. 1. - PP. 48-55].

6 Шерифф Р.Е., Грегори А.П., Вейл П.Р., Митчем Р.М. и др. Сейсмическая стратиграфия. / - М, Мир, 1982. - 846 с. [Sheriff R.E., Gregory A.P., Vail P.R., Mitchum R.M. Jr. and others. Seismic stratigraphy. / - M, Mir, 1982. - 846 s.].

7 Птецов С.Н. Анализ волновых полей для прогнозирования геологического разреза. / - М.: Недра, 1989. - 135 с. [Ptetsov S.N. Analysis of wave fields for predicting a geological section./ - M.: Nedra, 1989. - $135 \mathrm{~s}$.].

8 Череповский А.В. Миллион каналов и миллиард трасс в наземной сейсморазведке: актуально или нет? / Геофизика. - М. - 2020. - № 2. - С. 22-26. [A.V. Cherepovsky. A million channels and a billion traces in land seismic prospecting: is it relevant or not? / Geophysics. - M. - 2020. - No. 2. - PP. 22-26].

9 Калмагамбетов Ж.К. Сейсмика нефтяного месторождения и направления ее развития в Казахстане. / Нефть и газ. - 2020. - №1. - С. 33-41. [Kalmagambetov Zh.K. Seismics of an oil field and directions of its development in Kazakhstan. / Oil and gas. 2020. - No. 1. - PP. 33-41].

10 Sambell R. et al. Land seismic super-crew unlocks the Ara carbonate play of the Southern Oman Salt Basin with wide azimuth survey. / First Break. - Feb. 2010. - vol. 28. - PP. 61-68.

11 Шерифф Р., Гелдарт Л. Сейсморазведка. / В 2-х томах. - М. Мир, 1987. - 448 с. и 400 c. [Sheriff R., Geldart L. Seismic survey. / In 2 volumes. - M. Mir, 1987. - 448 s. and 400 s.].

12 Коростышевский М.Б., Сахаров А.Б., Смнева Д.А., Хайретдинова Е.М. Некоторые аспекты совместного использования данных глубинной миграции до суммирования и бурения. / Технологии сейсморазведки. - 2005. - № 1. - С. 52-56. [Korostyshevsky M.B., Sakharov A.B., Smneva D.A., Khairetdinova E.M. Some aspects of sharing prestack and drilling depth migration data / Technologies of seismic exploration. - No.1. - 2005. PP. 52-56].

13 Тяпкина А.Н., Тяпкин Ю.К., Окрепкий А.И. Адекватная скоростная модель - основа эфрективного построения сейсмических изображений при картировании ловушек углеводородов, связанных с соляными куполами. / Геофизический журнал. - 2015. T. 37. - №1. - C. 147-164. [Tyapkina A.N., Tyapkin Yu.K., Okrepky A.I. Adequate velocity model is the basis for efficient seismic imaging when mapping hydrocarbon traps associated with salt domes. / Geophysical journal. - 2015. - V. 37. - No. 1. - PP. 147-164].

14 Berkovitch A., Belfer I., Hassin Y. and Landa E. Diffraction Imaging by Multifocusing. I Geophysics. - November-December 2009. - Vol. 74. - No. 6. - WCA75-WCA81.

15 Цимбалюк Ю.А., Матигоров А.А., Беркович А. Мультифокусинг - новая технология обработки данных сейсморазведки / Нефтегазовая вертикаль. Спец. выпуск ЗапСибНИИГГ. - 2010. - С. 26-31. [Tsimbalyuk Yu.A., Matigorov A.A., Berkovich A. Multifocusing new processing technology of seismic data / Oil \& Gas Vertical. West-Siberian Scientific Research Institute of Geology and Geophysics special ed. - 2010. - PP. 26-31].

16 Berkovitch A., Deev K. and Landa E. How Non-hyperbolic MultiFocusing Improves Depth Imaging. / First Break, - September 2011. - Vol. 29. - PP. 95-103. 
17 Каковы основные недостатки и преимущества использования метода Мультифокусинга для обработки сейсмических данных? / Ланда Е., Балдин В., Хафизов С. и др. Oil \& Gas Journal Russia. - август 2012. - C. 48-50. [What are the main disadvantages and advantages of using the Multifocusing method for seismic data processing? / Landa E., Baldin V., Khafizov S. et al. - Oil \& Gas Journal Russia. - August 2012. - PP. 48-50].

18 Волож Ю.А., Трохименко М.С., Калимов А.М., Едилбаев М.Т. Каспийский регион: кольцевые субвертикальные стрктуры, покмарки и экс-покмарки (в 2-х частях). / Нефть и газ. - 2019. № 6. - С. 15-50 и - 2020. № 2. - C. 11-37. [Volozh Yu.A., Trokhimenko M.S., Kalimov A.M., Edilbaev M.T. Caspian region: circular sub-vertical structures, pockmarks and ex-pockmarks. / Oil and gas. - 2019. No. 6. PP. 15-50 and - 2020. No. 2. - PP. 11-37].

19 Berkovitch A., Deev K. and Landa E. Multifocusing-based multiple attenuation. / The Leading Edge. - October 2012. - PP. 1146-1152.

20 Москалев П.Ю. Современный подход к переобработке данных прошлых лет. / Нефть и газ. - 2020. - № 6. - С. 52-58. [Moskalev P.Yu. A modern approach to reprocessing data from past years. / Oil and gas. - 2020. - No. 6. - PP. 52-58].

21 Андреев В.Н., Блюменцвайг В.И., Глотов О.К. и др. Временные указания по методике поисков залежей нефти в ловушках неантиклинального типа./ - М., ИГиРГИ. 1986. 215 c. [Andreev V.N., Blumentsvaig V.I., Glotov O.K. et al. Temporary instructions on the method of prospecting for oil deposits in traps of non-anticlinal type. - M., IGiRGI. 1986. - 215 s.].

22 Матлошинский Н.Г., Таскинбаев К.М., Матлошинский Р.Н. и др. Неантиклинальные ловушки надсолевого комплекса Прикаспийской впадины: поиски, оценка и перспективы. / Нефть и газ. - 2019. - №6. - C. 51-68. [Matloshinsky N.G., Taskinbaev K.M., Matloshinsky R.N. et al. Non-anticlinal traps of the post-salt complex of the Caspian basin: search, assessment and prospects. / Oil and gas. - 2019. - No. 6. - PP. 51-68].

23. Волож Ю.А., Быкадоров В.А., Антипов М.П. и др. Типы высокоемких нефтегазолокализующих объектов подсолевого разреза Прикаспийской впадины. / Нефть и газ. - 2018. - №5. - C. 26-46. [Volozh Yu.A., Bykadorov V.A., Antipov M.P. and others. Types of high-capacity oil and gas localizing objects of the subsalt section of the Caspian depression. / Oil and gas. - 2018. - No. 5. - PP. 26-46].

24 Карабельников А., Куликова А., Невидимова А. И др., Применение технологии Мультифокусинг для переобработки сейсмических материалов по Русскому месторождению Запажной Сибири. / First Break. - 2008. - vol. 26. [Karabelnikov A., Kulikova A., Nevidimova A. et al., Application of Multifocusing technology for reprocessing seismic materials for the Russkoye field in Western Siberia. / First Break. - 2008. - vol. 26].

25 Кузнецова О.В., Караулов А.В., Цимбалюк Ю.А. Новые геотехнологии - для старых нефтегазоносных провинций. / Oil\&Gas Journal, - 2013. - 1-2. [Kuznetsova O.V, Karaulov A.V., Tsimbalyuk Yu.A. New geotechnologies - for old oil and gas provinces. / Oil \& Gas Journal. - 2013. - 1-2].

26 Куандыков Б.М., Волож Ю.А. Изучение глубокозалегающих горизонтов Прикаспийской впадины // Сборник «Нефтегазоносные бассейны Казахстана и перспективы их освоения». - Алматы: КОНГ. 2015. - С. 53-59. [Kuandykov B.M., Volozh Yu.A. The study of deep-seated horizons of the Pre-Caspian depression. Collection: "Oil and gas basins of Kazakhstan and prospects for their development". - Almaty: KONG. 2015. - PP. 53-59].

27 Исказиев К.О., Адилбеков К.А., Исенов С.М. Повышение качества сейсмического изображения при изучении глубоких палеозойских отложений. / Нефть и газ. - 2018. №1. - C. 52-64. [Iskaziev K.O., Adilbekov K.A., Issenov S.M. Improving the quality of seismic images in the study of deep Paleozoic deposits. / Oil and gas. - 2018. - No. 1. PP. 52-64]. 
28 Ланда Е. Обнаружение зон трещиноватости методом Дифракционного Мультифокусинга. / Oil \& Gas Journal Russia. - ноябрь, 2011. - С. 48-51. [Landa E. Detection of fracture zones by the method of Diffraction Multifocusing. / Oil \& Gas Journal Russia. November, 2011. - PP. 48-51].

29 Исенов С.М. Геотехнологии Мультифокусинг и Дифракционный Мультифокусинг новый уровень решения геологических задач. / Материалы совещания ООО «Газпром геологоразведка»: Развитие минерально-сырьевой базы газонефтедобычи в Восточной Сибири. - Красноярск. - 2013. - С. 114-121. [Issenov S.M. Multifocusing and Diffractive Multifocusing Geotechnologies - a new level of solving geological problems. / Materials of the meeting of Gazprom Geologorazvedka: Development of the mineral resource base for gas and oil production in Eastern Siberia. - Krasnoyarsk. - 2013. PP. 114-121].

30 Исенов С.М., Кузнецова О.В., Караулов А.В., Пельман Д. Технологии: Мультифокусинг и Дифракционный Мультифокусинг - новые перспективы детального изучения подсолевых карбонатных резервуаров в Прикаспийской впадине. / Нефтесервис. Лето 2014. - C. 32-34. [Issenov S.M., Kuznetsova O.V., Karaulov A.V., Pelman D. Technologies: Multifocusing and Diffraction Multifocusing - new perspectives for detailed study of subsalt carbonate reservoirs in the Pre-Caspian Basin. / Oilfield service. - Summer 2014. - РP. 32-34].

31 Ланда Е. Дифракционный мультифокусинг: оценка зон трещиноватости в баженовской свите. / Oil\&Gas Journal Russia. - 2013. - 8. [Landa E. Diffraction Multifocusing: assessment of fracture zones in the Bazhenov formation. Oil \& Gas Journal Russia. 2013. - 8]. 